\title{
The neuronal splicing factor Nova co-localizes with target RNAs in the dendrite
}

\author{
Claudia Racca ${ }^{1,2+}$, Alejandra Gardiol ${ }^{1,3+}$, Taesun Eom ${ }^{4 \dagger}$, Jernej Ule ${ }^{4,5}$, Antoine Triller $^{*}$ and Robert B. Darnell ${ }^{*}$ \\ ' Biologie Cellulaire de la Synapse Normale et Pathologique, Institut National de la Santé et de la Recherche Médicale, Ecole Normale Supérieure, Paris, France \\ 2 Institute of Neuroscience, Newcastle University, Newcastle upon Tyne, UK \\ 3 The Wellcome Trust CR UK Gurdon Institute, University of Cambridge, Cambridge, UK \\ ${ }^{4}$ Laboratory of Molecular Neuro-Oncology, Howard Hughes Medical Institute, The Rockefeller University, New York, NY, USA \\ ${ }^{5}$ Medical Research Council Laboratory of Molecular Biology, Cambridge, UK
}

\section{Edited by:}

Hollis Cline, The Scripps Research Institute, USA

\section{Reviewed by:} Science University, USA

Peter Vanderklish, Oregon Health and Science University, USA

\section{*Correspondence:}

Antoine Triller, Biologie Cellulaire de la Synapse Normale et Pathologique, Recherche Médicale U789, Ecole Normale Supérieure, 46 rue d'Ulm, F-75005 Paris, France

e-mail: triller@biologie.ens.fr

Robert B. Darnell, Laboratory of

Molecular Neuro-Oncology, Howard

Hughes Medical Institute, The

Rockefeller University, New York, NY

10021, USA.

${ }^{+}$Claudia Racca, Alejandra Gardiol and

Taesun Eom contributed equally to this

work
Soren Impey, Oregon Health and Institut National de la Santé et de la

e-mail: darnelr@rockefeller.edu

Nova proteins are neuron-specific RNA binding proteins targeted by autoantibodies in a disorder manifest by failure of motor inhibition, and they regulate splicing and alternative 3 ' processing. Nova regulates splicing of RNAs encoding synaptic proteins, including the inhibitory glycine receptor $\alpha 2$ subunit (GlyR $\alpha 2$ ), and binds to others, including the GIRK2 channel. We found that Nova harbors functional NES and NLS elements, shuttles between the nucleus and cytoplasm, and that $50 \%$ of the protein localizes to the soma-dendritic compartment. Immunofluoresence and EM analysis of spinal cord motor neurons demonstrated that Nova co-localizes beneath synaptic contacts in dendrites with the same RNA, GlyR $\alpha 2$, whose splicing it regulates in the nucleus. HITS-CLIP identified intronic and 3' UTR sites where Nova binds to GlyRo2 and GIRK2 transcripts in the brain. This led directly to the identification of a 3' UTR localization element that mediates Nova-dependent localization of GIRK2 in primary neurons. These data demonstrate that HITS-CLIP can identify functional RNA localization elements, and they suggest new links between the regulation of nuclear RNA processing and mRNA localization.

Keywords: RNA splicing, RNA localization, nova, HITS-CLIP, shuttling protein, GIRK2, glycine receptor, spinal motor neuron

\section{INTRODUCTION}

Posttranscriptional regulation is thought to play a crucial role in generating diversity in the postsynaptic dendrite. This includes links between RNA splicing, RNA localization, RNA translation and synaptic formation, long term potentiation and synaptic plasticity (Schuman et al., 2006; Sutton and Schuman, 2006; Lin and Holt, 2007; Richter and Klann, 2009). In some cases specific RNA binding proteins (RNABPs) have been correlated with this regulation, including actions of FMRP (Bassell and Warren, 2008), ZBP (Rodriguez et al., 2008), Nova (Huang et al., 2005; Ule and Darnell, 2006), CPEB (Richter, 2007) and others (Richter and Klann, 2009). In other cases, regulation of RNA metabolism, such as activitydependent alternative splicing and localization of NMDA receptor subunits (Ehlers et al., 1995; Mu et al., 2003), has been clearly defined, but the factors directly involved are only now beginning to be defined (Ule and Darnell, 2006).

Studies in Drosophila and tissue culture cells suggest that splicing may be mechanistically coupled to mRNA localization in the cytoplasm (Pinol-Roma and Dreyfuss, 1992; Luo and Reed, 1999; Kataoka et al., 2000; Le Hir et al., 2000; Hachet and Ephrussi, 2004). There is also emerging interest in the role of the $3^{\prime}$ UTR in RNA regulation in the synapse (Holt and Bullock, 2009). Neurons have been found to generate preferentially long $3^{\prime}$ UTRs (Wang et al., 2008) in a manner regulated by neuronal RNABPs (Licatalosi et al., 2008), and these are potential sites for controlling RNA turnover or regulation by miRNAs in the synapse, as suggested by studies of Arc (Bramham et al., 2008) or CaMKII synaptic RNAs (Ashraf et al., 2006). However, an important unresolved question is whether information generated by regulation of alternative RNA processing is tagged at the time it is generated in the nucleus or whether the complexity of RNA generated there is handled independently in the synapse. One means of exploring this question is to ask whether the regulatory RNABPs regulating alternative RNA processing of specific transcripts also participate in their synaptic regulation.

Nova-1 and Nova-2 comprise a family of neuron-specific RNABPs targeted in a paraneoplastic syndrome in which inhibitory control of motor systems is affected (Musunuru and Darnell, 2001; Darnell and Posner, 2003; Darnell, 2006). Nova proteins regulate alternative splicing in neurons (Jensen et al., 2000; Polydorides et al., 2000; Dredge and Darnell, 2003; Dredge et al., 2005; Ule et al., 2006, 2005; Licatalosi et al., 2008). In vitro, Nova binds an intronic YCAY-rich element in GlyRo2 pre-mRNA upstream of the mutually exclusive exons 3A (E3A) and E3B (Buckanovich and Darnell, 1997; Polydorides et al., 2000), and in co-transfection minigene assays this leads to preferential utilization of E3A (Jensen et al., 2000). It was subsequently recognized that Nova 
regulates numerous transcripts encoding synaptic proteins in the spinal cord and brain. Nova-null mice show defective splicing of inhibitory GlyR $\alpha 2$ receptors (Jensen et al., 2000), GABA receptors (Dredge and Darnell, 2003), the Nova-1 transcript itself (Dredge et al., 2005), and the neuron-specific isoform of agrin (Ruggiu et al., 2009). More generally, a combination of genome-wide screens for Nova targets, including exon junction arrays (Ule et al., 2005) and RNA-protein crosslinking (CLIP) methods (Ule et al., 2003, 2005; Jensen and Darnell, 2008; Licatalosi et al., 2008) coupled with additional biochemical and bioinformatic validation studies (Ule et al., 2006) (reviewed in Licatalosi and Darnell, 2010) have confirmed that Nova binds to YCAY-rich elements to regulate alternative splicing of a biologically coherent set of transcripts encoding synaptic proteins (Ule et al., 2005; Ule and Darnell, 2006).

Not all Nova-RNA targets are regulated at the level of alternative splicing. Nova is also able to bind 3' UTR elements to regulate alternative polyadenylation (Licatalosi et al., 2008), although other actions are less clear. For example, inhibitory responses to LTP (sIPSC of LTP) in the hippocampus were found to be dependent on Nova and on two of its target RNAs, encoding GIRK2 and GABA receptors (Huang et al., 2005), but the consequence of Nova binding to those transcripts is unknown. In motor neurons, Nova regulates $\mathrm{Z}^{+}$agrin splicing, but rescuing this activity failed to restore the ability of motor neurons to innervate muscle, and suggested additional defects proximal to the motor axon (Ruggiu et al., 2009).

The mounting evidence that nuclear RNA processing may also be coupled to RNA regulation in the cytoplasm, coupled with the detection of some Nova immunoreactivity in neuronal soma (Buckanovich et al., 1996; Polydorides et al., 2000), prompted us to investigate whether Nova might also act outside the nucleus. Here we show the existence of an abundant pool of cytoplasmic Nova. In tissue culture, Nova shuttles between the nucleus and cytoplasm, and it is required for RNA localization of the target GIRK2 mRNA in primary neurons. In vivo, the Nova target GlyR $\alpha 2$ mRNA is well documented to be transported to spinal motor neuron dendrites (Racca et al., 1997, 1998). We show that Nova is robustly detected in spinal motor neuron dendrites and, specifically, in inhibitory (gephyrin positive) synapses. Moreover, Nova co-localizes there with GlyR $\alpha$ mRNAs in spinal neurons, both in dendrites and beneath synapses, but is excluded from dendrites in the dorsal horn where GlyR $\alpha$ mRNAs do not extend into the dendritic tree (Racca et al., 1998). Finally, biochemical analysis using CLIP identifies binding sites in the GIRK2 3' UTR, and we find that Nova binding there is necessary for proper localization of GIRK2 mRNA in neuronal processes. Taken together, these data demonstrate that the splicing factor Nova and its nuclear RNA targets are also colocalized in dendrites close to synaptic contacts, suggesting a model in which the regulation of alternative splicing is coupled in cis to the expression of the same RNA in neuronal dendrites.

\section{RESULTS \\ NOVA LOCALIZATION AND SHUTTLING BETWEEN THE NUCLEUS AND CYTOPLASM}

To assess whether significant amounts of Nova protein are present in the brain outside of the nucleus, we performed Western blot analysis of nuclear and cytoplasmic fractions of mouse brain. Nova protein was readily detectable in both fractions, with the majority $(\sim 60 \%$, normalized to total protein) present in the nucleus (Figure 1A), consistent with its role as a nuclear splicing factor and the high concentration of nuclear Nova evident by immunofluorescence (below). Interestingly, when we normalized our input by loading equal volumes of brain cytoplasm and nuclear fractions, a measure of the total amount of Nova present in each, we found that two thirds $(68 \%)$ of total Nova protein is present in the cytoplasm (Figure 1A). Immunofluorescence microscopy using anti-Nova antibodies confirmed an abundance of Nova immunoreactivity both within and outside of the nucleus (Figure 1B). Taken together, these data demonstrate very significant amounts of Nova protein are present outside of the nucleus in mouse brain.

We asked whether Nova, like many RNABPs with this distribution, actively shuttles between the nucleus and cytoplasm. We assayed whether Nova endogenously expressed in a human neuroblastoma cell line (IMR-32) could shuttle into the nuclei of COS7 cells, an assay originally developed to document hnRNP-A1 shuttling (Pinol-Roma and Dreyfuss, 1992). Four hours after fusion, with de novo protein synthesis blocked, Nova appeared in the COS7 cell nuclei (Figure 2A). We repeated these experiments with fusions of another human neuroblastoma cell line [SK-N-BE(2)] and mouse 3T3 cells, again finding shuttling of endogenous Nova but not hnRNP-C1, a non-shuttling nuclear RNA binding protein (Figure 2B). We also confirmed these results using an overexpressed Flag epitope-tagged Nova protein after transfection into HEK293 T cells and fusion to the neuroblastoma line N2A (data not shown). Taken together, these data indicate that, in tissue culture cells, Nova acts as a shuttling protein.

To investigate whether specific Nova protein domains regulate its subcellular localization, we examined the localization of Flag-tagged Nova constructs harboring deletions in either putative nuclear localization sequences (NLS) or nuclear export sequences (NES) (based on sequence homology with known motifs; Figure 2C). Wild-type Flag-Nova was localized primarily to the nucleus of transfected COS7 cells, with some staining evident in the cytoplasm. In contrast constructs in which the putative NLS was deleted were localized in a reticular pattern in the cytoplasm, and constructs in

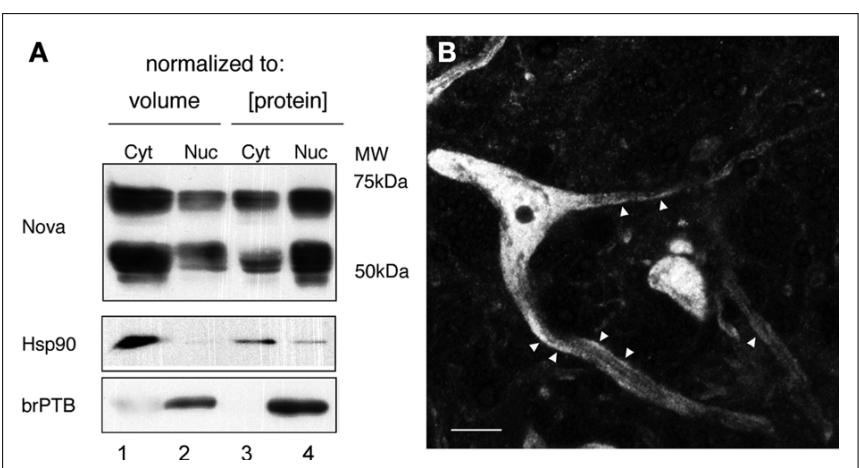

FIGURE 1 | Subcellular distribution of Nova proteins. (A) Immunoblot analysis of Nova distribution in cytoplasmic and nuclear fractions from mouse brain (equal volumes $(20 \mu \mathrm{l})$ of each fraction were loaded in lanes 1 and 2 ; equal protein amounts $(50 \mu \mathrm{g})$ were loaded in lanes 3 and 4). Hsp90 is used as a cytoplasmic marker, and brPTB as a nuclear marker. The antibody used detects both Nova 1 ( $\sim 55 \mathrm{kD})$ and Nova-2 ( 75 kD) isoforms. (B) Nova signal is detected within the nucleus, somatic cytoplasm, and neurites of ventral horn spinal cord neurons. Within neurites, the signal is observed along the plasma membrane (arrowheads). Scale bar: $10 \mu \mathrm{m}$ (B). 

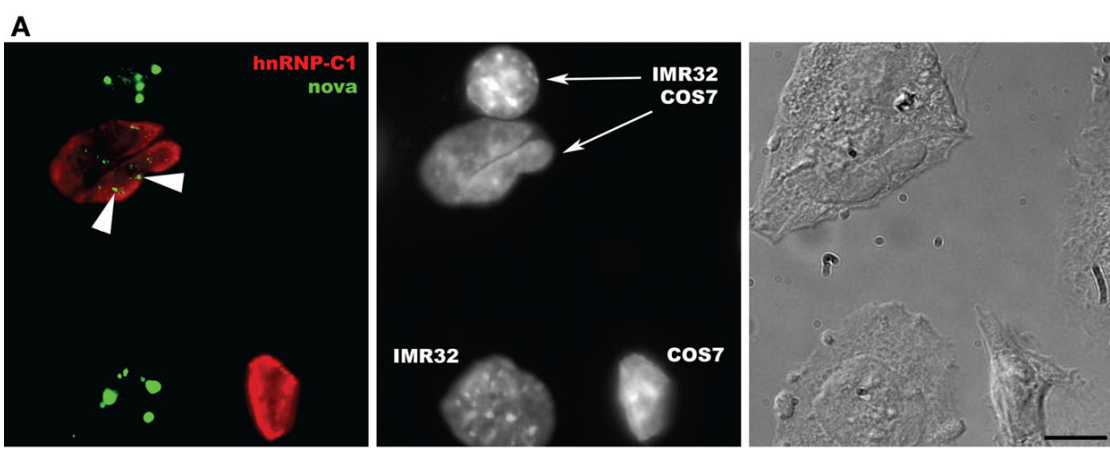
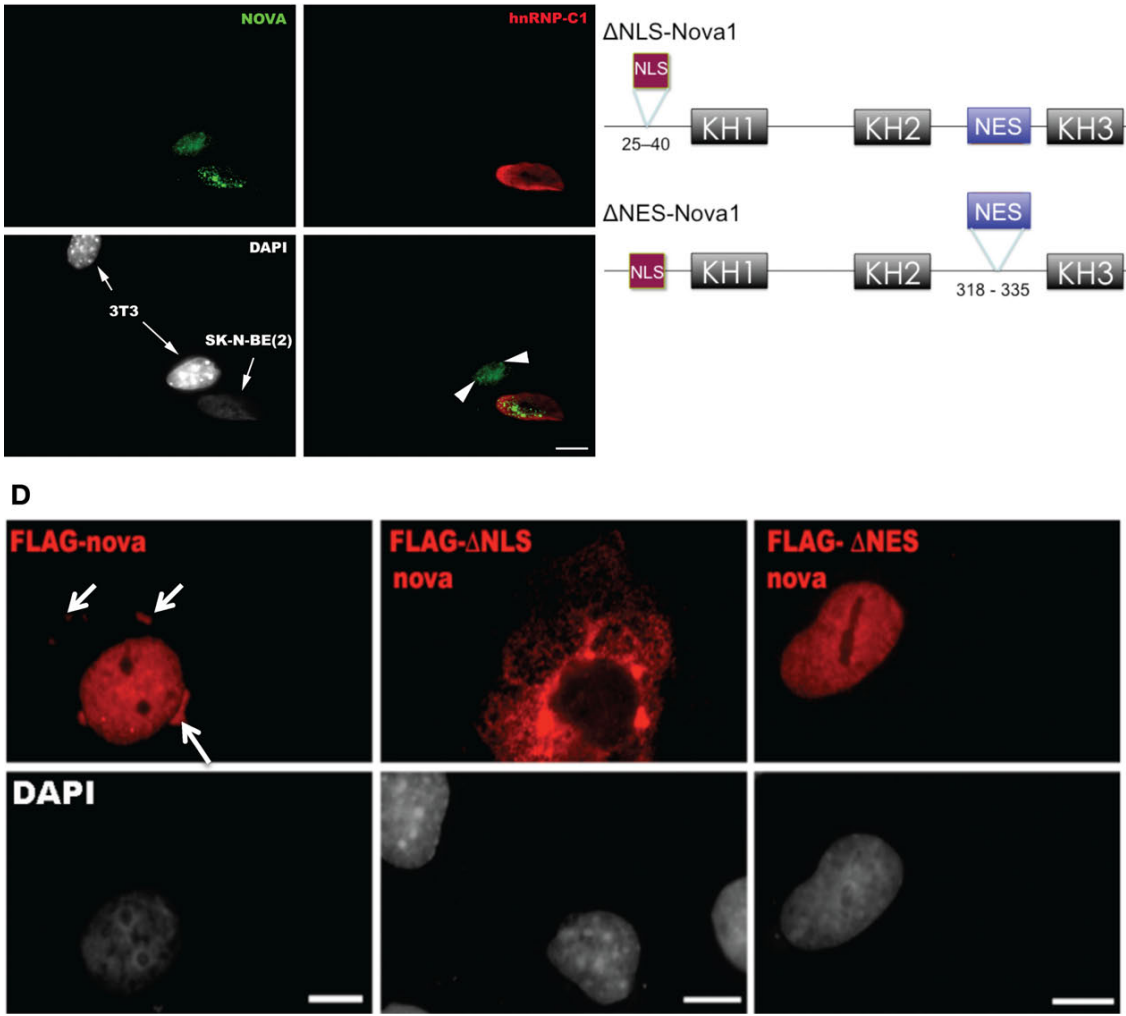

FIGURE 2 | Nova proteins shuttle between the nucleus and cytoplasm. (A) IMR32 and COS7 cells were fused with PEG 3350, and anti-hnRNPC1 and anti-Nova antibodies were used to detect endogenous proteins. In this field one cell has been fused with COS7 (top; see phase contrast, right panel), and two unfused cells are evident (bottom); cell types can be distinguished with DAPI staining (middle panel). Nova proteins were detected in IMR32 and fused COS7 cells (arrowheads), but no signal in isolated COS7 cells. DAPI staining showed IMR32 cells and COS7 cells, respectively. (B) Shuttling of endogenous Nova from
SK-N-BE(2) neuroblastoma cells into mouse NIH 3T3 cells; Nova, hnRNP-C12 and DAPI stains are shown as in (A). (C) Schematic of Flag-tagged Nova NLS and NES domains and deletion constructs generated. (D) COS7 cells were transfected with the indicated Flag-Nova1 plasmid constructs and stained with anti-flag antibody to visualize flag-Nova1 (top panels), and DAPI to visualize nuclei (bottom panels). Nova1 can be seen in the cytoplasm in cells transfected with the WT (left panel; arrows) but not in cells transfected with the $\triangle \mathrm{NES}$ construct (right panel); in contrast the $\Delta \mathrm{NLS}$ construct is largely excluded from nuclei (middle panel). which the putative NES was deleted were localized exclusively in the nucleus (Figure 2D). These observations define distinct Nova domains that harbor NLS and NES activity.

These observations led us to examine Nova distribution in spinal motor neurons in greater detail. We found that the dendrites of most of the neurons in the intermediate zone and ventral horn were strongly immunopositive for Nova. Dendritic staining had a punctate pattern and tended to localize peripherally to the dendritic axial core and accumulate at dendritic branch points (Figure 1B; see also Figures $4 A, B$ ). The ultrastructural localization of Nova within neurons was investigated using pre- and post-embedding electron microscopy (EM) immunocytochemistry. EM confirmed the nuclear and cytoplasmic localization of Nova. Neuronal nuclei were heavily stained by Nova (Figure 3A). Nuclear chromatin can be either highly condensed and scattered within the nucleoplasm or relaxed, depending on the neuronal subtype (Peters et al., 1991). 


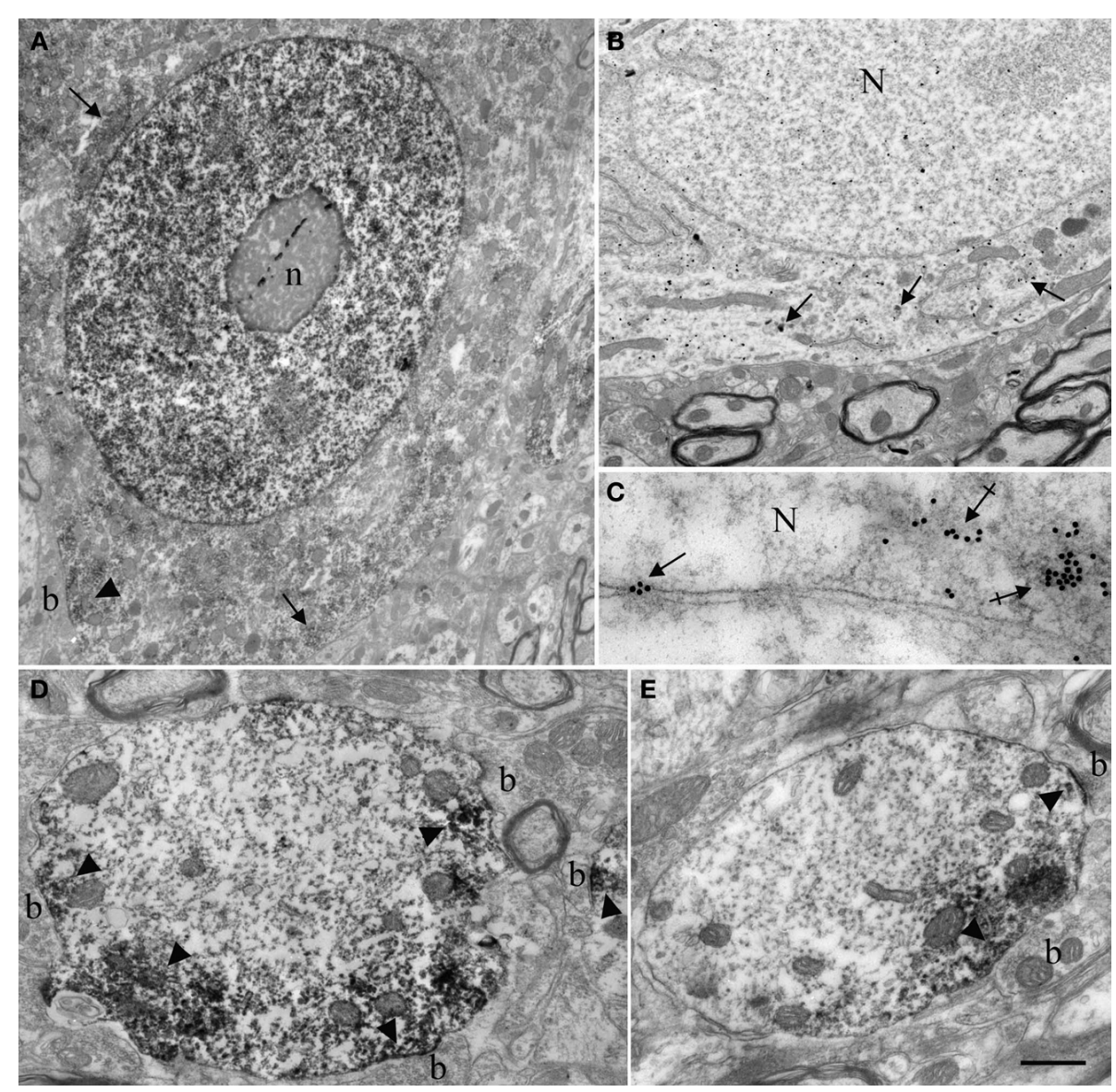

FIGURE 3 | Ultrastructural localization of Nova in the somata and dendrites of ventral horn spinal cord neurons. (A,B) Micrographs of pre-embedding immunocytochemistry experiments. (C) Micrograph of a post-embedding immunocytochemistry experiment. (A) Distribution of Nova visualized with electron dense HRP reaction product (arrows). The nucleus is heavily stained but not the nucleolus ( $n$ ). Presence of electron dense HRP reaction product (arrowhead) in front of a synaptic contact (b). (B) Gold particles associated with Nova are found within the nucleus (N), as well as within the somatic cytoplasm (arrows). (C) High magnification micrograph of the nuclear periphery. In spinal neuron nuclei $(\mathrm{N})$, where the chromatin is condensed at the nuclear periphery in proximity of the inner side of the nuclear membrane, Nova ( $15 \mathrm{~nm}$ gold particles) accumulates over chromatin (crossed arrows) and can be found within nuclear pores (arrow). (D,E) Electron microscopic immunolabeling of Nova in dendrites (HRP reaction product) showing Nova tendency to accumulate peripherally to the dendritic center, and close to synapses (arrowheads). Axons are devoid of staining. Boutons (b). Scale bar: $4 \mu \mathrm{m}$ (A); $2 \mu \mathrm{m}$ (B); $0.3 \mu \mathrm{m}$ (C); $1 \mu \mathrm{m}$ (D,E).
In neurons where the chromatin was relaxed (Figures 3A,B), Nova signal was not associated with any identifiable intranuclear structures. In contrast, in nuclei where the chromatin was highly condensed, especially when apposed to the nuclear membrane, Nova immunoreactivity was concentrated over these chromatin-dense regions (Figure 3C). In post-embedding experiments, Nova immunoreactivity was often observed near and within nuclear pores (Figure 3C). In the somatic cytoplasm, the labeling was scattered and tended to be in proximity of or associated with cisternae of the endoplasmic reticulum. Nova immunoreactivity could also be observed close to postsynaptic specializations (Figures 3A,D,E). Within dendrites, Nova was mainly peripheral along the plasma membrane, in the proximity of synaptic contacts (Figures 3D,E).

\section{NOVA IS PRESENT AT INHIBITORY SYNAPSES}

Immunoelectron microscopy for Nova (Figures 4A,B) and doubleimmunofluorescence for Nova and synapsin (Figures 4A,B insets), a presynaptic marker (Bloom et al., 1979; De Camilli et al., 1979,
1983), confirmed the presence of Nova protein at synapses. To assess whether Nova protein was present at inhibitory synapses, we examined whether Nova and gephyrin reactivity co-localized. Gephyrin is considered a postsynaptic marker of inhibitory synapses (Triller et al., 1985, 1987; Altschuler et al., 1986). Both immunofluoresence and immuno EM demonstrated that Nova immunoreactivity is present in the somato-dendritic cytoplasm of postsynaptic inhibitory differentiations identified by a strong labeling for gephyrin (Figures 4C-E and inset).

\section{LOCALIZATION OF NOVA-RNA TARGETS}

Nova binds to GlyR $\alpha 2$ pre-mRNA to regulate alternative splicing within the nucleus (Buckanovich et al., 1996; Buckanovich and Darnell, 1997; Jensen et al., 2000). To examine whether Nova might play a role in the regulation of mRNAs within dendrites, we took advantage of the observation that GlyR $\alpha 2$ mRNA is present at inhibitory synapses and in dendrites (Racca et al., 1997). Costaining of spinal cord motor neurons for Nova proteins and 


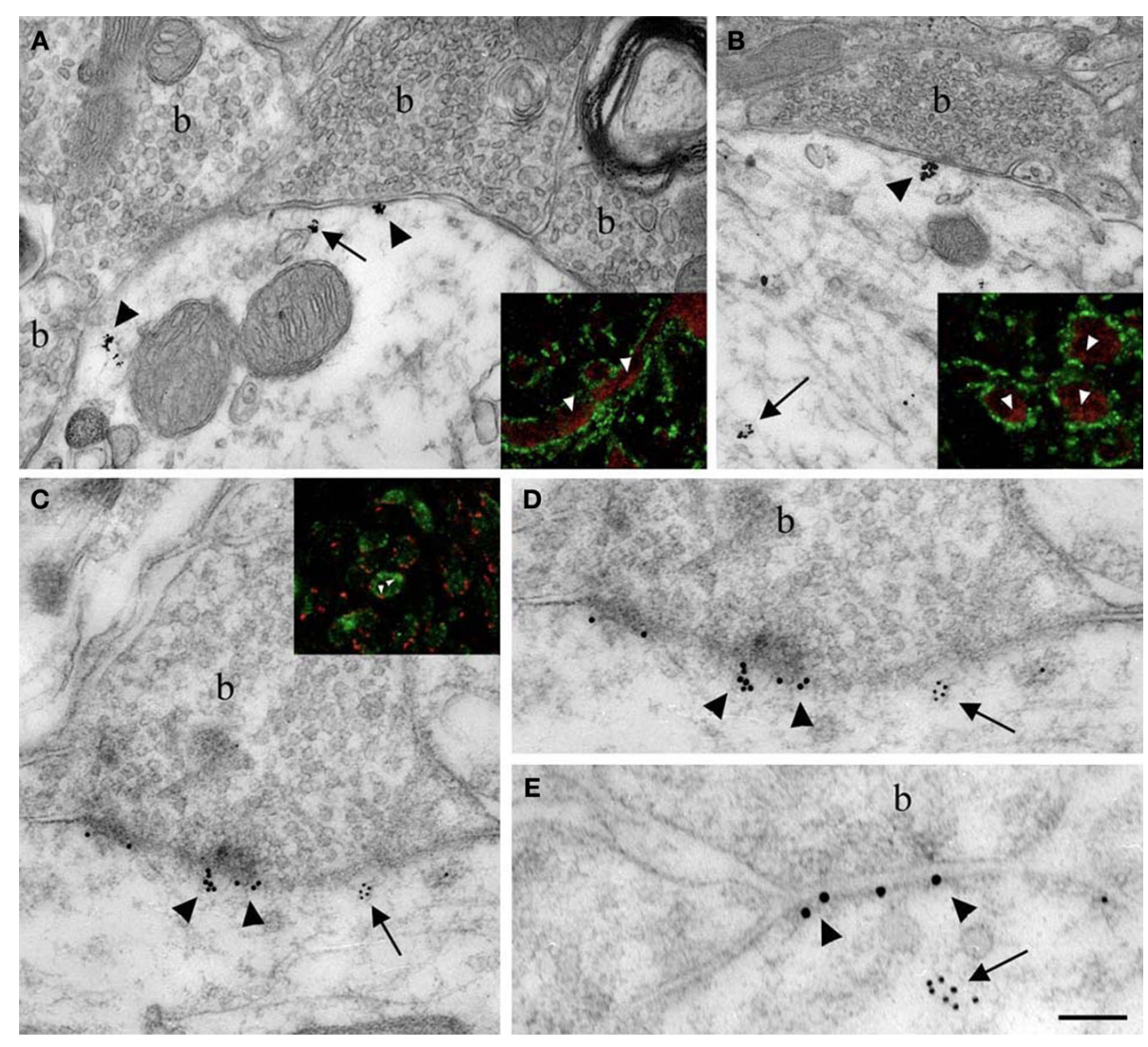

FIGURE 4 | Localization of Nova at inhibitory synapses. (A,B) Nova signal detected by gold labeling (arrows) is observed in dendrite and opposed to boutons (b) at the dendritic periphery (arrowheads). Insets in (A) and (B),

Double-immunofluorescence detection of Nova (in red) and synapsin (in green) show that Nova immunoreactivity is present opposite to synaptic contacts (arrowheads). (C,D,E) Simultaneous detection of Nova and gephyrin immunoreactivity within the postsynaptic cytoplasm. Nova immunoreactivity
(10 nm gold particles; arrows) is found beneath postsynaptic regions where gephyrin immunoreactivity (15 nm gold particles; arrowheads) decorates and identifies inhibitory synapses. (D) High magnification of the postsynaptic cytoplasm of (C). Inset in (C), Double-immunofluorescence of Nova (in green) and gephyrin (in red) showed that Nova immunoreactivity is observed in proximity of gephyrin immunoreactivity synaptic contacts (arrowheads). Scale bar: $0.2 \mu \mathrm{m}(\mathbf{A})$; $0.6 \mu \mathrm{m}$ (B); $0.2 \mu \mathrm{m}$ (C,E); $0.4 \mu \mathrm{m}$ (D); $9 \mu \mathrm{m}$ (insets in $\mathbf{A}, \mathbf{B}$ ); $6 \mu \mathrm{m}$ (inset in $\mathbf{C}$ ).
GlyR $\alpha 2$ mRNA by EM and fluorescence microscopy revealed that Nova protein co-localizes with GlyR $\alpha 2 \mathrm{mRNA}$ in the dendrite (Figure 5). GlyR $\alpha 2$ and GlyR $\alpha 1$ mRNA have previously been shown to co-localize (Racca et al., 1997), and we found that Nova protein and GlyR $\alpha 1 \mathrm{mRNA}$ also co-localize (Figure 5A). In the dorsal horn of the spinal cord, GlyR $\alpha 2$ mRNA transcripts do not translocate to dendrites, but are restricted to the neuronal somata (Racca et al., 1998). Interestingly, in these neurons Nova immunoreactivity was restricted to somata as well (Figure 5C).

Electron microscopy confirmed that Nova protein and GlyR $\alpha 2$ mRNA are co-localized within dendrites of spinal cord motor neurons. Here, as previously reported (Racca et al., 1997), subsynaptic GlyR $\alpha$ mRNA was often detected in association with small cisternae (Figures 5E,G) belonging to a protein synthesis-related subsynaptic apparatus (Gardiol et al., 1999), and this mRNA again co-localized with Nova protein. GlyR $\alpha 2$ mRNA and Nova protein were also associated with postsynaptic differentiations in the vicinity of these minute subsynaptic cisternae, suggestive of a protein synthesis-related subsynaptic machinery, and consistent with the nature of GlyR $\alpha 2$ proteins as transmembrane proteins (Figures 5D-G).
The spinal cord of Nova-null mice show defects in alternative splicing of RNAs encoding synaptic proteins (Ule et al., 2005). To explore whether Nova-RNA targets are mislocalized in Nova-null neurons, we established primary neuronal cultures from E18.5 embryos of WT and Nova1/2 null ("DKO") mice. Interestingly, although GlyR $\alpha 2$ transcripts are localized in spinal motor neurons in adult animals (Racca et al., 1997, 1998), both this localization and the level of transcript expression (Kuhse et al., 1991; Malosio et al., 1991) is developmentally regulated such that mRNA localization does not become evident until after the second postnatal week (C. Racca, unpublished data). Since Nova DKO mice die at birth (Ule et al., 2006; Ruggiu et al., 2009), Nova 1 null animals die in the first 7-10 days postnatally (Jensen et al., 2000) and Nova2 null animals usually die in the second postnatal week, we examined mRNA localization of a different Nova target.

We have previously shown that the ability of GIRK2 to mediate potentiation of slow inhibitory postsynaptic currents is Novadependent (Huang et al., 2005). While the mechanism of Nova action on GIRK2 mRNA has not been determined, Nova CLIP data (Ule et al., 2003) previously indicated that Nova directly binds to 


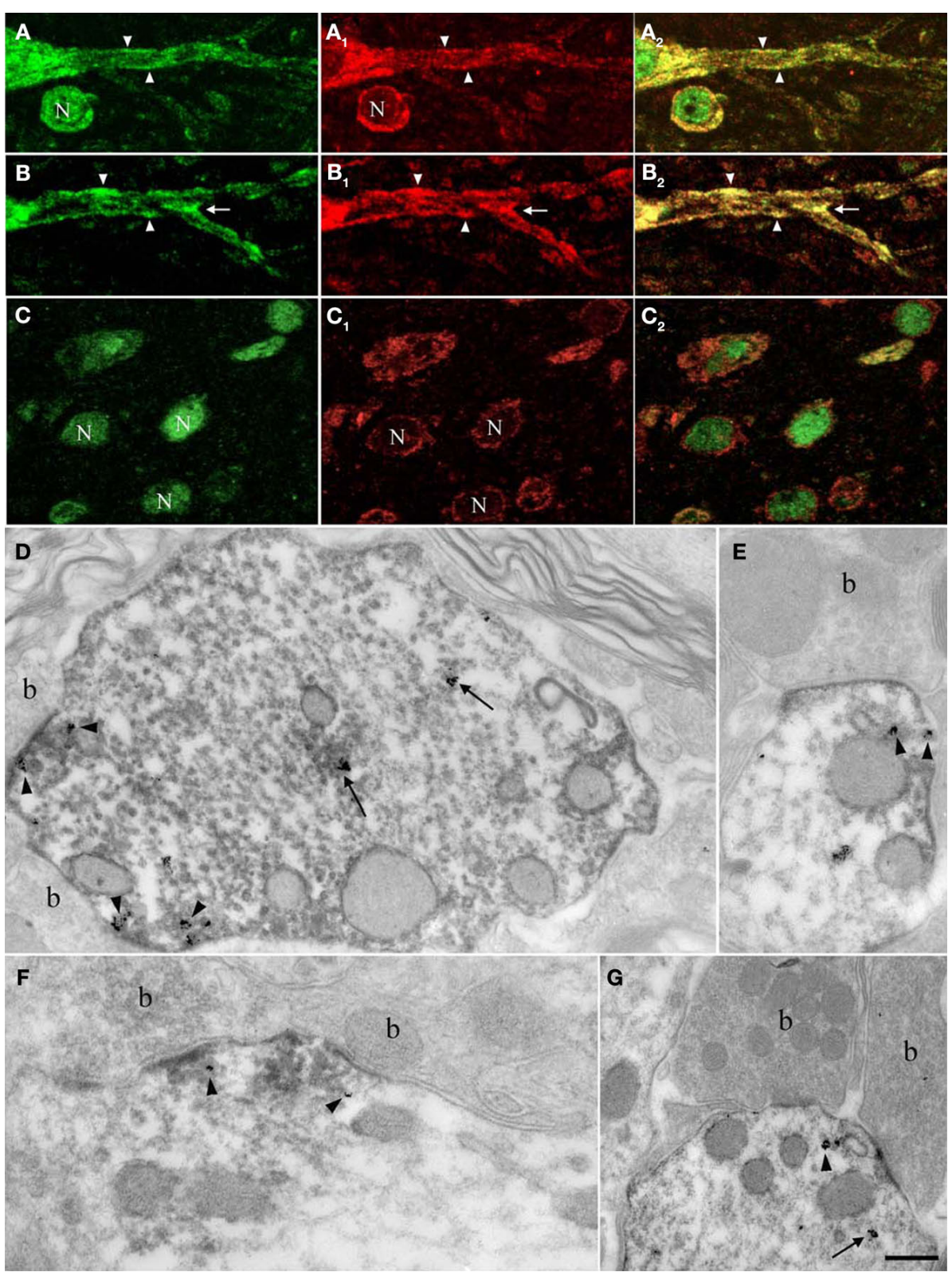

FIGURE 5 | Nova and GlyR $\alpha 2$ mRNAs, its nuclear alternative splicing RNA target, colocalize outside the nucleus within dendrites. Fluorescence labeling for Nova immunoreactivity (in green; $\mathbf{A}, \mathbf{B}, \mathbf{C}$ ) and ISH signal (in red) for GlyR $\alpha 1$ (A1) or GlyRo2 mRNAs (B1,C1). (A)Within the somatic and dendritic cytoplasm of ventral horn neurons, GlyR $\alpha 1 / 2(\mathrm{~A} 1, \mathrm{~B} 1) \mathrm{mRNAs}$ and Nova $(\mathbf{A}, \mathbf{B})$ labeling colocalizes (in yellow; A1,B1). The labeling pattern of Nova mirrors that of GlyR $\alpha 1 / 2$ mRNAs. Both are also unevenly distributed within the dendritic cytoplasm and sometimes accumulate at the dendritic periphery (A,B; arrowheads) and branch points (B; arrows). Note that the signal corresponding to Nova protein or GlyR $\alpha 1 / 2$
mRNAs are separated in some areas. (C) in neurons of the dorsal horn, where GlyR $\alpha 2$ mRNA (C1) is restricted to the somatic cytoplasm, Nova immunoreactivity is detected in nuclei (N) and to a lesser extent in somatic cytoplasm (C) resulting in a less accentuated co-localization (C2). (D-G) Ultrastructural simultaneous detection of Nova immunoreactivity and GlyR $\alpha 2$ mRNAs. Nova (HRP immunolabeling) and GlyR $\alpha 2$ mRNA ISH signal (gold particles) colocalize within the dendritic cytoplasm (arrows) and in front of synaptic boutons (arrowheads, b). Note in $(\mathbf{E}, \mathbf{G})$ the association of Nova and mRNA signals with small cisternae. Scale bar: $15 \mu \mathrm{m}$ (A-C); $0.2 \mu \mathrm{m}$ (D-F); $0.35 \mu \mathrm{m}$ (G)
GIRK2 intronic pre-mRNA (intron 2). Moreover, GIRK2 mRNA has multiple isoforms, including at least three different alternative $3^{\prime}$ UTRs, which we confirmed by RT-PCR (data not shown). To address which, if any, of these isoforms Nova might directly bind to, we searched a robust map of Nova-RNA interactions in the brain developed using HITS-CLIP (Licatalosi et al., 2008).
This revealed a cluster of Nova CLIP tags (representing in vivo protein-RNA binding) within the distal-most 3' UTR of GIRK2 mRNA (isoform GIRK2-1; see Materials and Methods), which was enriched in the Nova binding element YCAY (Figure 6A). Additional upstream binding sites were also present in the GIRK2 transcript, most notably in the intronic region between the 
A Girk2-1 3'UTR Nova binding motif

TGATGCTGGG CTCCTAGTGT GGATCAAGAA GTGTTCCTTC TAAGCTCATC 94970826

CTCTGACAGA CATTACAGAG AACTGATATA TTTTTCCTCC TTCACTGCTT 94970776

GGAAGAATTC ACCCAGAATT CACCCAACCC ATCTGGACCT AGTACATTCT 94970726

CGCCGCGGtt aagatggtt attgctcttg cagacggcct gggttcagtt 94970626

Chr16: $94,971,500$

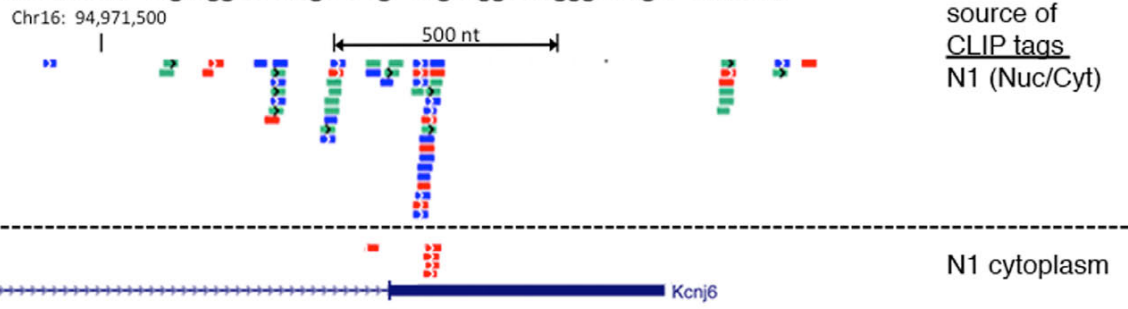

B

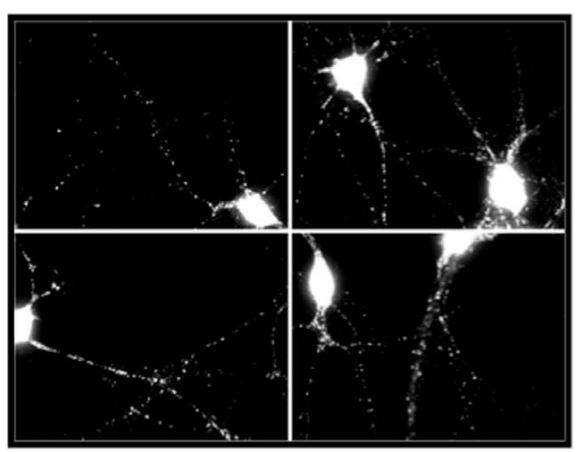

D

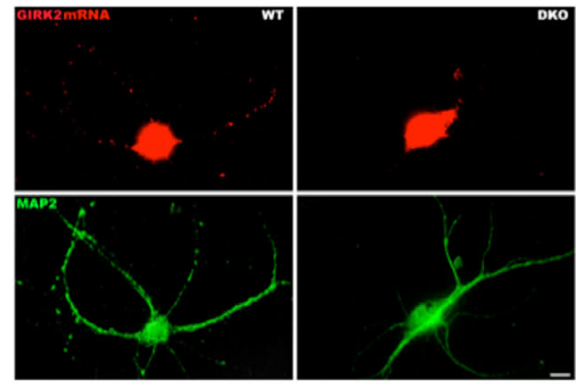

C

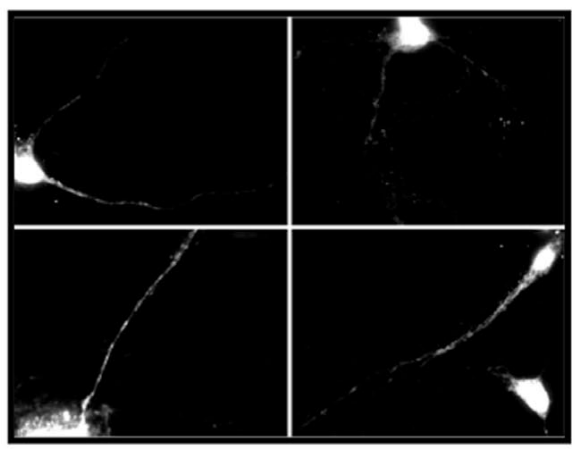

$\mathbf{E}$

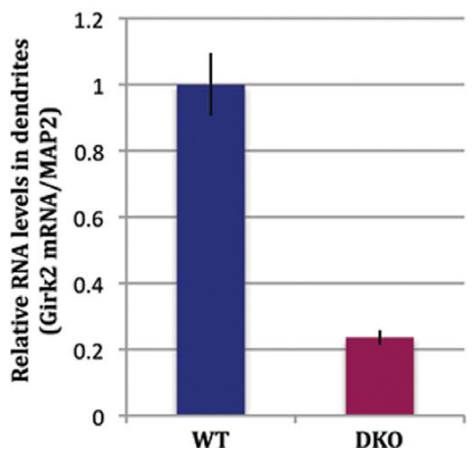

(D) Comparison of GIRK2-1 FISH and MAP2 immunoreactivity in WT and Nova DKO primary neurons, as indicated. (E) Quantitation of fluorescence intensity from (D); MAP2 fluorescence signal was counted beginning 5-10 $\mu \mathrm{m}$ from the cell body and extended to the distal dendrites, and then the signal from GIRK2-1 was obtained from the same dendrite; at least 10 neurons were counted in each of three experiments. The results from a three independent experiments are plotted as the sum of the dendritic signal from GIRK2-1 (Cy3) divided by MAP2 (Cy5); error bars represent standard deviation ( $p<0.05$; Student's $t$-test). The MAP2 signal alone was not significantly changed in WT vs. KO neurons (data not shown). Sense strand oligonucleotides were used as a negative control and showed no signal under identical conditions. Scale bar: $10 \mu \mathrm{m}$ (D) annotated GIRK2a-1 and GIRK2-1 3' UTRs, and in the intron 2 site previously identified ( $\sim 187,000 \mathrm{nt}$ upstream of the $3^{\prime}$ UTR). We confirmed that Nova was bound to the mature GIRK2 mRNA in neuronal cytoplasm by repeating CLIP in a cytoplasmic brain fraction (data not shown and Figure 6A). The protein and transcript levels of GIRK2 remained unchanged in WT compared to
Nova DKO brain (unpublished data). Taken together, these data suggested that Nova might act upon the GIRK2 3' UTR element to regulate mRNA localization.

We therefore set out to examine localization of the GIRK2-1 isoform in neurons. We assessed GIRK2 mRNA localization using a set of Cy3-conjugated oligonucleotide probes directed at the GIRK2-1 
3' UTR extension in Nova WT and KO neurons. These probes did not yield a sufficient signal:noise to detect GIRK2 RNA isoforms in E18.5 brain sections (perhaps due to low expression of the GIRK2 and GIRK2-1 isoform; for example, as assessed by Affymetrix arrays of E18.5 mouse brain, the transcript normalized probe intensity for GIRK2 was 199, and for GIRK2-1 was $\sim 50$, relative to a median of 708; data not shown). We therefore assessed GIRK2-1 mRNA localization in primary cultures of cortical neurons. These in situ hybridization (ISH) results demonstrated that GIRK2-1 mRNA extended from the cell soma into dendritic processes of WT neurons, where it was present in a punctate pattern. In contrast, in Nova DKO neurons, GIRK2 mRNA was restricted to the cell body and proximal dendrites, where it was present in a diffuse pattern (Figures 6B,C). Quantitation of the fluorescence signal from GIRK2 mRNA in WT vs. Nova DKO dendrites, normalized to the immunofluorescence signal from MAP2, demonstrated 3-fold decrease in dendritic GIRK2 mRNA in DKO neurons $(p<0.05$; Figures $6 \mathrm{D}, \mathrm{E})$. We note also that mRNA appears to be more granular in WT compared to KO neurons; whether this relates to a role for Nova in mediating granule inclusion in dendrites for the localization of mRNAs it regulates is not known.

To address whether direct Nova binding to the GIRK2 3' UTR (YCAY) ${ }_{4}$ element could localize the mRNA, we developed a reporter assay in $\mathrm{N} 2 \mathrm{~A}$ (neuroblastoma) tissue culture cells. We generated a construct encoding a destabilized d1EGFP (which has a short half life of $\sim 1 \mathrm{~h}$, giving an image skewed toward detection of local protein expression) fused to a nuclear localization element (M9) and either a $208 \mathrm{nt}$ fragment from the wild-type GIRK2 3' UTR or a mutant 208 nt fragment which would abrogate Nova binding [in which the four YCAY repeats were mutated to YGUY; (Buckanovich and Darnell, 1997; Lewis et al., 2000); Figure 7A]. Expression of d1EGFP outside the nucleus was used as an indirect measure of GIRK2-1 mRNA localization. Cells transfected with the WT YCAY construct showed a clear and quantifiable increase in d1EGFP localization to distal neurites, while d1EGFP expression in cells transfected with the mutant YGUY construct was largely restricted to the cell body (Figures 7B,C), while the d1EGFP signal in the soma was not significantly changed. Interestingly, the T7-Nova signal also appeared more prominent in distal neurites in cells transfected with the WT YCAY construct, while the MAP2 signal was not changed, suggest that direct Nova binding to GIRK2 3' UTR is necessary for proper localization of the mRNA.

The action of Nova to regulate GlyR $\alpha 2$ pre-mRNA splicing and its co-localization with GlyR $\alpha 2$ mRNA suggests that protein may be bound to both GlyR $\alpha 2$ pre-mRNA and mature mRNA. We addressed this possibility by again examining Nova HITSCLIP data (Licatalosi et al., 2008). Figure 8A illustrates the intronic region of GlyR $\alpha 2$ pre-mRNA previously shown in vitro and in minigene assays to mediate Nova-dependent inclusion of E3A (Buckanovich and Darnell, 1997; Polydorides et al., 2000). Remarkably, the intronic Nova binding motif (YCAY clusters) is surrounded by several Nova CLIP tags (Figure 8A). In addition, examination of the $3^{\prime}$ UTR revealed several clusters of Nova CLIP tags, both around the stop codon and within the $3^{\prime}$ UTR itself (Figure 8B). This co-incidence of tags in the intron and $3^{\prime}$ UTR also led us to re-examine intronic tags in GIRK2 pre-mRNA; an extremely robust tag cluster (identified in at least 17 different mouse CLIP experiments, from a variety of tissues, including neocortex, hippocampus and spinal cord) was identified harboring 13 YCAY elements within 1123 nucleotides (see Figure 6 legend). These data suggest a model in which intronic loading of Nova in the nucleus may couple regulation of pre-mRNA RNA metabolism (e.g. splicing) to $3^{\prime}$ UTR loading and regulation of mRNA expression (e.g. mRNA localization; Figure 9).

\section{DISCUSSION}

Nova functions as a neuron-specific alternative splicing factor (Jensen et al., 2000; Dredge and Darnell, 2003; Ule et al., 2003; Dredge et al., 2005; Licatalosi et al., 2008), but we find here that the amount of Nova in the soma-dendritic compartment is at least as great as that in the nucleus. In ventral horn motor neurons, Nova proteins are localized within the nucleus, cytoplasm and dendrites and were often apposed to inhibitory synapses. Nova regulates the splicing of GlyR 22 mRNA (Buckanovich and Darnell, 1997), a transcript known to be transported to the dendrites (Racca et al., 1997), and we find here that Nova protein and GlyR $\alpha$ mRNA colocalize within the dendrite (Figure 5), consistent with the finding that Nova binds directly to GlyR $\alpha$ pre-mRNA and 3' UTR within the brain. In addition, Nova was required for proper localization of GIRK2 mRNA in primary neuronal cultures. Taken together, these observations suggest that the role of Nova in RNA regulation goes beyond its actions in the nucleus, such that it is able to act to coordinate nuclear RNA processing with local mRNA expression. Moreover, since Nova is critical for the normal physiology of motor neurons (Ruggiu et al., 2009) and hippocampal neurons (Huang et al., 2005), and at least in motor neurons, correction of a Novadependent $\mathrm{Z}^{+}$agrin splicing defect failed to rescue the physiologic defect (paralysis) in Nova DKO mice, it is possible that such actions may play critical roles in CNS neurons.

\section{NOVA PROTEINS AND THE INHIBITORY SYNAPSE}

Nova proteins are the neuron-specific target antigens in a paraneoplastic neurological disorder, Paraneoplastic Opsoclonus Myoclonus and Ataxia (POMA; Darnell and Posner, 2006). Clinically, POMA symptoms suggest an impairment of CNS inhibition. Interestingly, these clinical observations correlate with the finding that Nova proteins bind to introns, exons and UTRs of many RNAs encoding components of the inhibitory synapse [e.g. subunits of the GlyR and $\mathrm{GABA}_{\mathrm{A}}$ and $\mathrm{GABA}_{\mathrm{B}}$ receptors, gephyrin, GIRK2 and others (Jensen et al., 2000; Dredge and Darnell, 2003; Ule et al., 2003, 2005; Ule and Darnell, 2006; Licatalosi et al., 2008)]. GlyR $\alpha 2$ subunit and gephyrin mRNAs encode components of the inhibitory glycinergic synapse (Moss and Smart, 2001). GIRK2 encodes a G protein-activated inwardly rectifying $\mathrm{K}^{+}$channel that mediates $\mathrm{GABA}_{\mathrm{B}}$ inhibition in a Nova-dependent manner. We have found a physiologically relevant action of Nova that appears to be specific to one alternatively processed GIRK2 isoform. Nova binds to a YCAY element in the GIRK2-1 3' UTRs and localizes GIRK2-1 mRNA, but we found no evidence for Nova-dependent localization of other GIRK2 mRNA isoforms (data not shown). These data are most consistent with a model in which Nova binds to a 3' UTR element to mediate mRNA localization, as observed for many other protein-RNA interactions (Kislauskis and Singer, 1992; Bassell and Singer, 2001; Palacios and St Johnston, 2001; Martin and Ephrussi, 2009). 
A

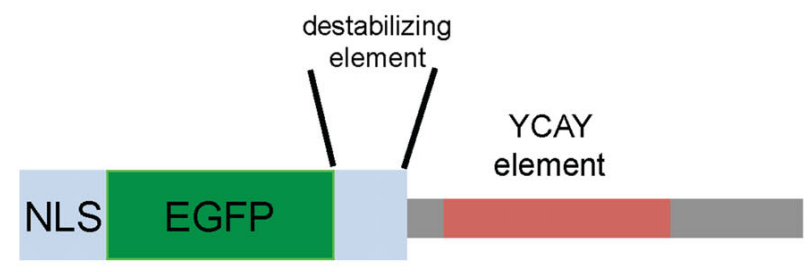

B
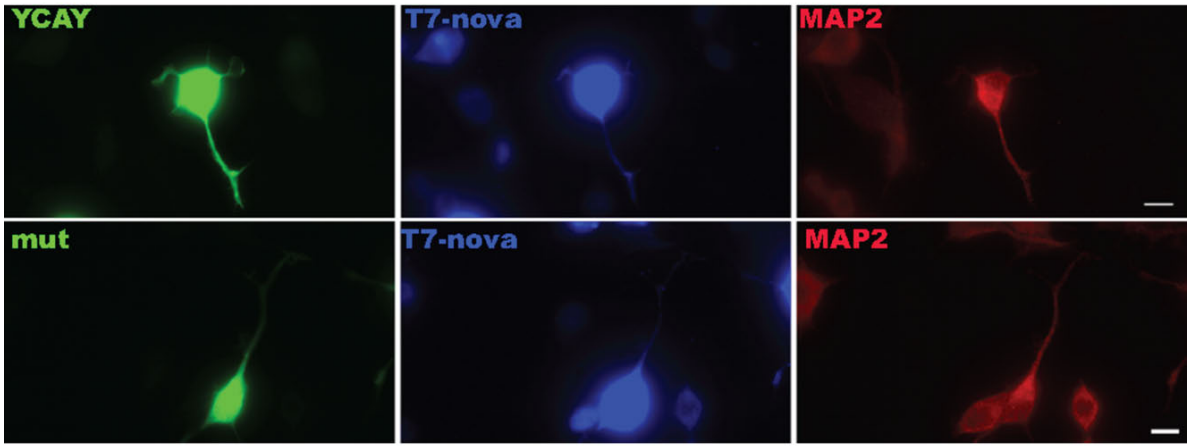

C

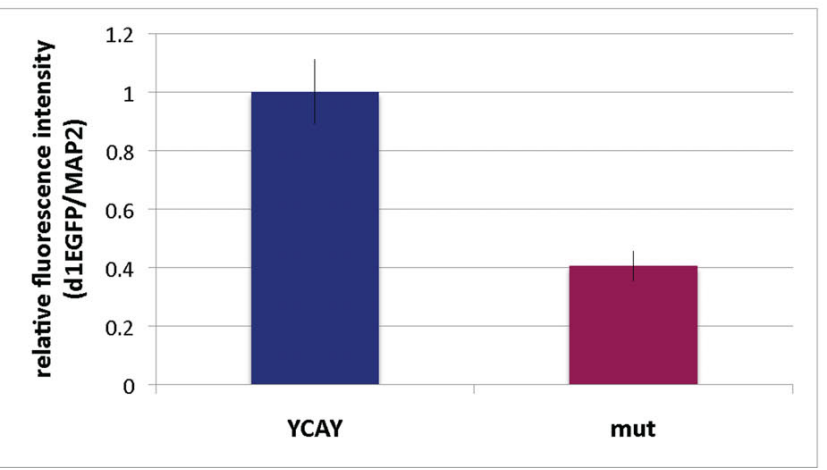

FIGURE 7 | Binding of Nova to the GIRK2-1 YCAY element is necessary for proper localization. (A) Schematic of a reporter encoding destabilized d1 EGFP with an M9 nuclear localization sequence (NLS) and the 3' UTR GIRK2-1 YCAY element. An identical construct in which the four YCAY sequences were mutated to YGUY was also made. (B) Comparison of EGFP and MAP2 immunoreactivity in cells co-transfected with plasmid constructs encoding the YCAY or the mutant ("mut") YGUY element, as indicated, and a construct expressing T7-tagged Nova. The WT Nova target mRNA (green channel, left panel) was localized in distal neurites in transfecting cells expressing the YCAY but not mutant GIRK2-1 element; T7-tagged Nova itself, detected with T7 antibody (middle panel) also appeared more localized in distal dendrites, while MAP2 (right panel) was unchanged in either condition. (C) Quantitation of EGFP fluorescence intensity from (B); Region of Interest (ROI) was chosen based on neurite in which MAP2 fluorescence signal was detected, beginning $5 \mu \mathrm{m}$ from the cell body and extending outwards. The signal from d1EGFP was obtained from the same ROI; more than 10 cells were counted. The results are plotted as relative ratio of the sum of the neurite signal from d1EGFP (Cy2) divided by MAP2 (Cy3) in YCAY element or mutated constructs; error bars represent standard deviation $(p<0.05)$; results are from three independent experiments. Scale bar: $10 \mu \mathrm{m}$ (B).
More is known about the action of Nova on the RNAs encoding the $\mathrm{GABA}_{\mathrm{A}}$ and GlyR $\alpha 2$ transcripts, where specific YCAY binding sites have been mapped within introns that mediate Nova-dependent alternative exon usage (Buckanovich and Darnell, 1997; Jensen et al., 2000; Dredge and Darnell, 2003). Here we provide convergent data demonstrating that Nova is present in the nucleus and, along with GlyR $\alpha$ mRNAs and gephyrin, within the dendrites and in the vicinity of inhibitory synapses in central neurons. These findings suggest that Nova might provide a means to couple nuclear RNA binding to the dendritic and subsynaptic localization of GlyR $\alpha 2$ mRNA. This could ultimately regulate the composition or number of glycine receptors at inhibitory synapses and, consequently, synaptic function. More generally, the localization of Nova in the inhibitory synapse predicts the possibility that the physiology of these synapses may show Nova-dependent features, perhaps reflected in the finding that inhibitory responses to LTP in the hippocampus are absent in Nova-null mouse brain (Huang et al., 2005).

In the nucleus, Nova binding to GlyR $\alpha 2$ pre-mRNA leads to prevalent expression of GlyR $\alpha 2 \mathrm{~A}$ subunit mRNA (Jensen et al., 2000). Both GlyR $\alpha 2 \mathrm{~A}$ and $2 \mathrm{~B}$ subunit mRNAs are expressed prenatally in the CNS (Kuhse et al., 1990, 1991). After postnatal day 5 the expression of GlyR $\alpha 2 \mathrm{~B}$ subunit mRNA decreases, whereas the expression 
A Glra2 intronic Nova binding motif

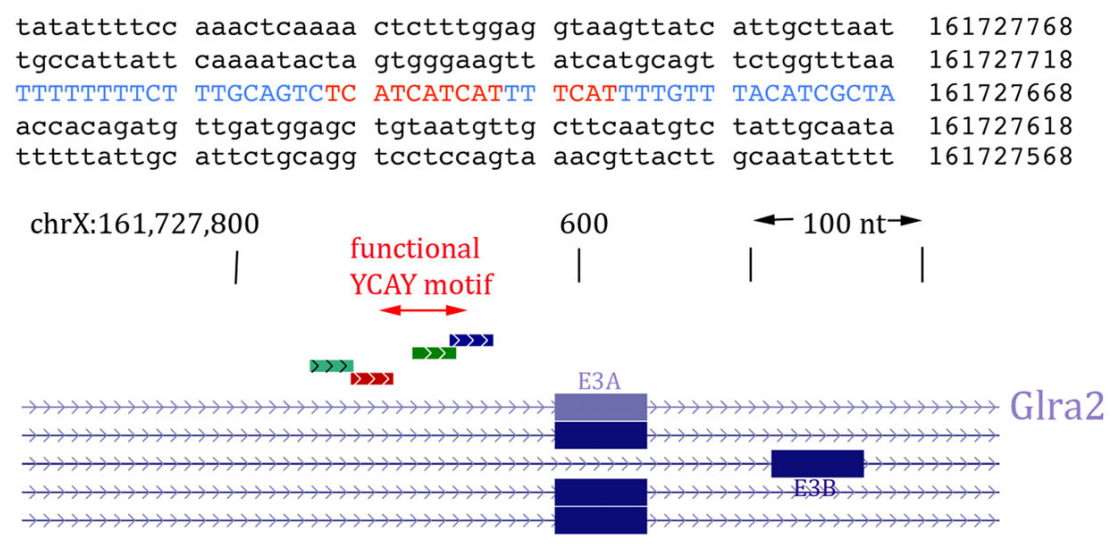

B Glra2 3'UTR Nova binding motifs

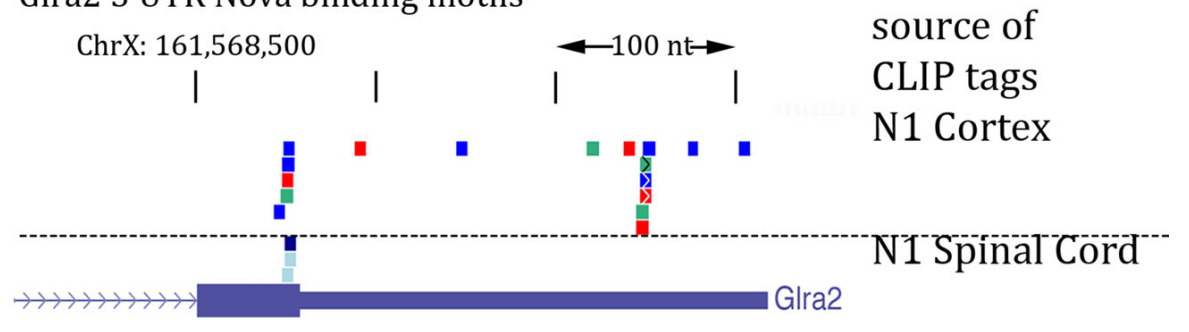

FIGURE 8 | Location of Nova CLIP tags in the GlyR $\alpha 2$ transcript. (A) The sequence of the previously characterized Nova binding YCAY motif upstream of GlyR $\alpha 2$ exon 3A is shown (blue); mutation of these YCAY elements (red) abrogates E3A splicing (Buckanovich and Darnell, 1997). Lower panel shows Nova HITS-CLIP tags in this intronic region. (B) Nova HITS-CLIP tags in the GlyRa2 3' UTR. In (A,B) Nova tags are colored as in Figure 6. level of GlyR $\alpha 2 \mathrm{~A}$ subunit mRNA is not altered (Kuhse et al., 1991). Interestingly, the localization of GlyR $\alpha$ subunit mRNAs to dendrites is also developmentally regulated and starts occurring after the second postnatal week (C. Racca, unpublished data). This observation meant that we focused our studies on adult animals, and were not able to study GlyR $\alpha 2$ subunit mRNA localization in Nova KO mice (which typically die in early postnatal life; Jensen et al., 2000). Nonetheless, the data suggest that the main form of GlyR $\alpha 2$ subunit mRNA present in dendrites is likely to be GlyR $\alpha 2 \mathrm{~A}$, the one also favored by Nova-mediated splicing. GlyRs containing either $\alpha 2 \mathrm{~A}$ or $\alpha 2 \mathrm{~B}$ subunit differ in their agonist sensitivity (Miller et al., 2004), such that those containing $\alpha 2 \mathrm{~B}$ subunit are more sensitive to agonists (glycine, alanine and taurine) than are those containing $\alpha 2 \mathrm{~A}$. Although yet to be proved, our data raise the possibility that neurons modulate their ligand sensitivity by local regulation, through Nova-mediated regulation of splicing, localization and/or expression of GlyR $\alpha 2 \mathrm{~A}$ mRNA.

\section{SUBSYNAPTIC RNPS COULD BE ASSEMBLED IN THE NUCLEUS IN A SPLICING-DEPENDENT MANNER}

Nova proteins were detected in the nucleoplasm, nuclear pores, and within the somato-dendritic cytoplasm, co-localized with target mRNAs. Although functional Nova binding sites were originally identified as intronic elements, the protein also binds to exons and 3' UTR regions of different RNAs (Darnell, 2006; Licatalosi et al., 2008). However, it has been unclear whether there is any relationship between these disparate binding sites. GlyR $\alpha$ mRNA is a robust transcript for addressing this question for two reasons. Nova binding sites in intron 3 were necessary to mediate alternative splicing in minigene assays (Buckanovich and Darnell, 1997; Polydorides et al., 2000). At the same time, GlyR $\alpha$ mRNAs are among the best documented dendritically localized transcripts (Racca et al., 1998; Steward and Schuman, 2001). The subcellular localization of Nova within dendrites of ventral horn but not dorsal horn spinal cord neurons parallels the dendritic localization of GlyR $\alpha$ subunit mRNAs (Figures 5A-C). The co-localization of Nova protein, GlyR $\alpha 2$ and GIRK2 mRNA outside of the nucleus, together with HITS-CLIP data demonstrating direct Nova binding to GlyR $\alpha 2$ and GIRK2 intronic and 3' UTR elements (Figures 6 and 8) indicate a link between the nuclear and cytoplasmic actions of Nova. Nova interacts with each transcript both prior to nuclear processing, as pre-mRNA, and after processing and cytoplasmic transport.

One plausible scenario by which Nova regulates both GlyR $\alpha 2$ pre-mRNA splicing and GlyR $\alpha 2$ mRNA localization/expression would be via independent binding to intronic and 3' UTR elements, as suggested for the localization of oskar mRNA in Drosophila oocytes (Hachet and Ephrussi, 2004). Binding to both sites could also be linked within the nucleus, for example by co-deposition of Nova in cis on introns and 3' elements of the same transcript. A more complex possibility invokes a direct link between the two, 


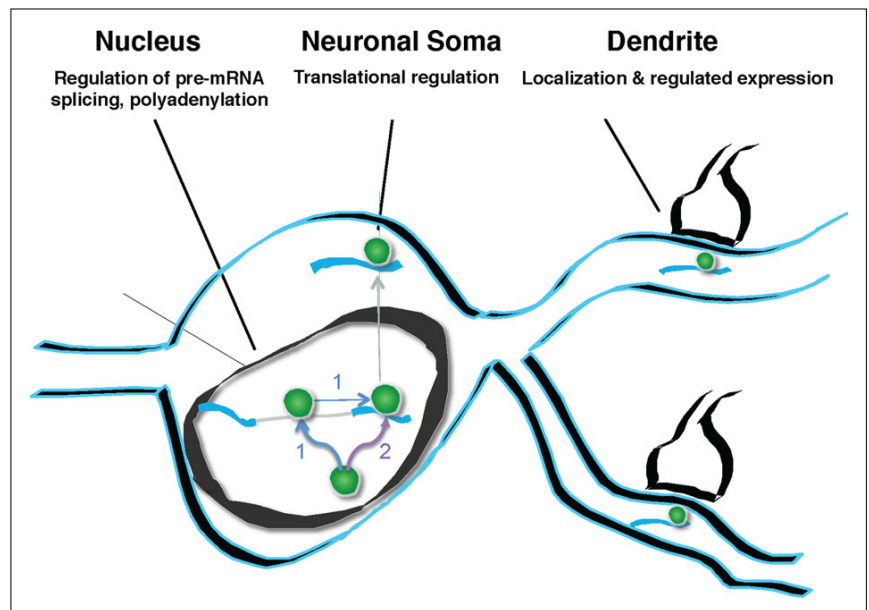

FIGURE 9 | Model of Nova action. Nova binds to pre-mRNA in the nucleus. This binding can, but need not be intronic (pathway labeled " 1 "). If binding sites are in the region of alternatively spliced exons, Nova can mediate alternative splicing, according to the rules of a functional binding map, such that the position of Nova binding determines the outcome of alternative exon inclusion. Subsequently, Nova may multimerize in cis upon the same transcript (pathway 1), or may be independently deposited upon additional mRNA binding sites, such as those in the 3' UTR (pathway labeled "2"). 3' UTR binding sites may determine additional processing steps (such as mediating alternative polyadenylation), and mediate soma and dendritic mRNA localization (as in the case of GIRK2-1 and perhaps GlyR 22 mRNA). It is presumed, based for example on the studies of Singer and colleagues (Lawrence and Singer, 1986; Kislauskis et al., 1997; Rodriguez et al., 2008), that such RNA localization would be coupled to the regulation of translation. In neurons, coupling pre-mRNA binding to $\mathrm{mRNA}$ localization and translation offers the possibility of linking information content generated in the nucleus (alternative splicing or polyadenylation) with differential gene expression in dendrites. non-specifically searching for high affinity binding sites present in cis (Elf et al., 2007; Gorman et al., 2007; Gorman and Greene, 2008; Visnapuu and Greene, 2009).

Such diffusion and multimerization around binding sites may be considered for Nova based on several observations: clusters of YCAY elements are seen in both the GlyR $\alpha 2$ and GIRK2 intronic and $3^{\prime}$ UTR elements (Figures 6 and 8), these are necessary for Nova-dependent action (splicing for GlyR $\alpha$ (Jensen et al., 2000) and localization for GIRK2-1, Figure 7), and clusters of binding elements may more generally be important to allow a sufficient concentration of RNABPs for effector action (Martin and Ephrussi, 2009). Although the results in overexpression transfection studies (Figure 7) were done with reporters that do not have introns, and therefore suggest that Nova binding the $3^{\prime}$ UTR can localize mRNA without prior intronic binding, the effects on localization were smaller than that quantitated for native GIRK2-1 RNA localization (Figure 6), and do not preclude the possibility that intronic binding may precede localization in systems in which RNABP/RNAs are not overexpressed (i.e. in the nervous system). An interesting feature of a model in which Nova splicing is coupled to $3^{\prime}$ UTR deposition is that it predicts that Nova binding to premRNA might be directly coupled both to generation of a specific spliced isoform (e.g. GlyR $\alpha 2-E 3 A$ mRNA), and to its subsequent somato-dendritic localization and protein expression (Figure 9). Assessment of this model will require careful biochemical mapping and coordination of key Nova binding sites from among the many identified intronic and $3^{\prime}$ UTR binding sites identified by HITSCLIP (Licatalosi et al., 2008).

Another, and not mutually exclusive factor that might influence Nova assembly with mature mRNA is through interaction with other RNABPs recruited onto the mature mRNA, as suggested for bicoid mRNA and several other localized RNAs (Arn et al., 2003; Martin and Ephrussi, 2009). Vegetal pole ribonucleoprotein particles assembled in Xenopus oocyte nuclei change upon export to the cytoplasm, where the RNA-protein complexes can recruit new RNABPs (Kress et al., 2004). Such RNA-protein complexes are believed to be the substrates of mRNA localization and are assembled by the recruitment of trans-acting factors, including motor proteins and the interaction of RNABPs with cis-acting sequences often situated in the $3^{\prime}$ UTR regions. These cis-acting sequences are believed to be sufficient to mediate the localization of the mRNA (St Johnston, 2005). This view has been challenged by the demonstration that, at least in the case of oskar, splicing and 3' UTR sequences are independent requirements for mRNA localization (Hachet and Ephrussi, 2004). Indeed, this and previous works (Hachet and Ephrussi, 2001; Palacios et al., 2004) suggest that cytoplasmic localization of an mRNA could be linked to the splicing-dependent deposition of RNABPs at the junction of the freshly assembled exons (Palacios, 2002; Giorgi and Moore, 2007). Hints of similar phenomenon are beginning to emerge from studies of mammalian ZBP RNABPs (ZBP1 with ZBP2, also known as KSRP), which are capable of localizing mRNAs harboring cis-acting sequences, and also interact with proteins implicated in regulating alternative splicing (Gu et al., 2002; Rodriguez et al., 2008). Thus the association of Nova with GlyR pre-mRNA may lead to deposition of factors that mark the mature mRNA with cis-acting RNABPs, presumably including Nova itself, that help direct the subsequent localization of the mRNA. 


\section{MATERIALS AND METHODS NUCLEAR/CYTOPLASMIC FRACTIONATION METHOD}

Brain tissue was Dounce homogenized in cold $10 \mathrm{mM}$ HEPES $(\mathrm{pH}$ 7.9), $10 \mathrm{mM} \mathrm{NaCl}, 1.5 \mathrm{mM} \mathrm{MgCl}, 0.2 \%$ Triton $\mathrm{X}-100,10 \mathrm{mM} \mathrm{NaF}$, protease inhibitors (Roche) and spun at $3000 \times \mathrm{g}$ for $3 \mathrm{~min}$. Supernatant was collected as cytoplasmic fraction, and pellet was resuspended in $20 \mathrm{mM}$ HEPES (pH 7.9), 25\% glycerol, $1.5 \mathrm{mM} \mathrm{MgCl}_{2}, 1.4 \mathrm{mM}$ $\mathrm{KCl}, 0.2 \mathrm{mM}$ EDTA, $0.5 \%$ NP-40, $10 \mathrm{mM}$ NaF, protease inhibitors (Roche) and $5 \%$ DNase, incubated $5 \mathrm{~min}$ at $37^{\circ} \mathrm{C}$, dialyzed against $1 \times$ PBS, pH 7.4, $1.5 \mathrm{mM} \mathrm{MgCl}_{2}, 0.5 \% \mathrm{NP}-40,10 \mathrm{mM} \mathrm{NaF}$, and collected as nuclear fraction. Both fractions were diluted to the same final volume and ultracentrifuged at $100,000 \times \mathrm{g}$ for $30 \mathrm{~min}$.

\section{IMMUNOBLOT ANALYSIS}

Equal volumes $(20 \mu \mathrm{l})$ or equal total protein amounts $(50 \mu \mathrm{g})$ were loaded onto $10 \%$ SDS-PAGE gels, and transferred to PVDF membranes (Millipore). Membranes were blocked and incubated with primary antibodies including rabbit anti-Nova (1:750) (Buckanovich and Darnell, 1997), mouse anti-Hsp90 (1:1000; Transduction laboratories), and rabbit anti-brPTB (Polydorides et al., 2000).

\section{OLIGONUCLEOTIDE PROBES}

Oligonucleotide probes encoded: $\alpha 1$ residues $1050-1094$ and 1096-1143 (Grenningloh et al., 1987; Malosio et al., 1991; Racca et al., 1997, 1998); $\alpha 2$ residues 1682-1726 and 1789-1810 (Kuhse et al., 1990; Malosio et al., 1991; Racca et al., 1997, 1998).

\section{PRIMARY ANTIBODIES}

Different antibodies, all giving the same pattern of staining (data not shown), were used at appropriate concentrations depending on the experiment to detect Nova epitopes. Affinity-purified rabbit anti-Nova (Yang et al., 1998); human sera from POMA patients; affinity-purified human anti-Nova; mouse monoclonal antibody anti-gephyrin (Pfeiffer et al., 1984); rabbit anti-synapsin (Bloom et al., 1979; De Camilli et al., 1979).

Specific antibodies and concentrations used in each figure are listed:

Figure 1B: Single IC: anti-Nova human serum (1:1000); Goat anti-Human FITC (Jackson) 1:200

Figures 3A,D,E: anti-Nova Rabbit Purified (1:750); Goat antiRabbit Biotinylated (Vector) 1:200

Figure 3B: anti-Nova human serum (1:1000); Goat anti-Human Nanogold, $1 \mathrm{~nm}$ (Nanoprobrobes) 1:50

Figure 3C: anti-Nova Rabbit serum (1:200); Goat anti-Rabbit, $15 \mathrm{~nm}$ Gold particle (British Biocell) 1:50

Figures 4A,B: anti-Nova human serum (1:1000); Goat antiHuman Nanogold, $1 \mathrm{~nm}$ (Nanoprobrobes) 1:50

Figures 4C-E: anti-Nova Rabbit serum (1:400); Goat antiRabbit, 10 nm Gold particle (British Biocell) 1:50 + anti-Gephyrin Mouse mAb (Boehringer Mannheim)1:100; Goat anti-Mouse, $15 \mathrm{~nm}$ Gold particle (British Biocell) 1:50

Figure 4 inset in A and B: anti-Nova human serum (1:1000); Goat anti-Human FITC (Jackson) 1:200 + anti-Synapsin Rabbit Serum 1:6000; Goat anti-Rabbit Cy3 (Jackson) 1:200

Figure 4 inset in C: anti-Nova Rabbit Purified (1:750); Goat antiRabbitFITC (Jackson) 1:200 + anti-Gephyrin Mouse mAb (Boeringher Mannheim) 1:100; Goat anti-Mouse Cy3 (Jackson) 1:200
Figures 5A-C: anti-Nova Rabbit Purified (1:750); Goat antiRabbit FITC (Jackson) 1:200; and for ISH: Sheep anti-DIG (Boehringer Mannheim) 1:1000/donkey anti-Sheep Cy3 (Jackson) $1: 200$

Figures 5D-G: anti-Nova human serum (1:200); Goat antiHuman Biotinylated (Vector) 1:200 and for ISH Sheep anti-DIG Nanogold, $1 \mathrm{~nm}$ (Nanoprobrobes) 1:50

\section{TISSUE PREPARATION}

This study was performed in full accordance with the European Communities Council Directives (86/609/EEC) and the French national Committee (87/848) recommendations and the Rockefeller University Animal Care and Use Committee guidelines. Adult Sprague-Dawley rats (Janvier, France) were deeply anaesthetized with pentobarbital (60 mg/kg body weight, i.p.), and intracardially perfused. For fluorescent immunocytochemistry and in situ hybridization (ISH) animals were perfused with $4 \%$ paraformaldehyde (PFA) in phosphate buffer saline $(0.1 \mathrm{M}, \mathrm{pH}$ 7.2; PBS). For EM immunocytochemistry and ISH animals were perfused with $4 \%$ PFA and $0.1 \%$ glutaraldehyde in PBS. Spinal cords were removed and postfixed in 4\% PFA in PBS overnight at $4{ }^{\circ} \mathrm{C}$. Spinal cord sections were cut onto a vibratome and collected in PBS.

\section{FLUORESCENT IMMUNOCYTOCHEMISTRY ON SPINAL CORD SECTIONS}

Spinal cord $30 \mu \mathrm{m}$ sections were rinsed in $50 \mathrm{mM} \mathrm{NH}_{4} \mathrm{Cl}$ in PBS for $15 \mathrm{~min}$, and permeabilized with $0.1 \%$ Triton $\mathrm{X}-100,0.1 \%$ bovine gelatin in PBS for $10 \mathrm{~min}$. The primary antibodies were incubated in the same buffer overnight at $4^{\circ} \mathrm{C}$. Sections were then rinsed in PBS $(3 \times 10 \mathrm{~min}$ each $)$ and incubated for $2 \mathrm{~h}$ at room temperature (RT) with the corresponding fluorescent secondary antibodies (carboxymethyl indocyanine ( $\mathrm{Cy} 3$ ) or fluorescein isothiocyanate (FITC); Jackson ImmunoRes Labs (West Grove, PA, USA), in $0.1 \%$ bovine gelatin in PBS). After three washes in PBS (10 min each), sections were mounted on slides with Vectashield (Vector Lab.).

\section{FLUORESCENT IN SITUHYBRIDIZATION AND IMMUNOCYTOCHEMISTRY ON SPINAL CORD SECTIONS}

Fluorescent in situ hybridization (ISH) was as previously described (Racca et al., 1997, 1998). Digoxigenin labeled probes and Nova proteins were contemporaneously revealed in $100 \mathrm{mM}$ Tris- $\mathrm{HCl}$ $\mathrm{pH} 7.5,150 \mathrm{mM} \mathrm{NaCl}, 2 \% \mathrm{BSA}, 0.3 \%$ Triton X-100, overnight, $4{ }^{\circ} \mathrm{C}$. The anti-digoxigenin and anti-Nova primary antibodies were detected by incubating sections with the appropriate secondary antibodies (in PBS, $2 \mathrm{~h}$ at RT). Each incubation was followed by three washes in PBS (10 min each). Finally, sections were mounted on slides with Vectashield (Vector Lab.)

\section{IMAGE ACQUISITION}

The sections processed for fluorescent immunocytochemistry and ISH were observed with an epifluorescent Zeiss microscope, or a Leica confocal laser scanning microscope. All images presented here were obtained with the Leica confocal laser scanning microscope. For confocal images the background noise was reduced by applying a Gaussian filter to the optical sections. 


\section{ELECTRON MICROSCOPIC IMMUNOCYTOCHEMISTRY}

$100 \mu \mathrm{m}$ thick vibratome sections were cryoprotected in $20 \%$ glycerol-20\% sucrose in PBS, and permeabilized by freezing and thawing. Sections were collected in PBS, rinsed in $50 \mathrm{mM} \mathrm{NH}_{4} \mathrm{Cl}$ in PBS for $15 \mathrm{~min}$, and $0.1 \%$ bovine gelatin in PBS for $10 \mathrm{~min}$. The free-floating sections were incubated with the primary antibodies in $0.1 \%$ bovine gelatin in PBS, overnight, at $4^{\circ} \mathrm{C}$. The following day, sections were rinsed three times in PBS (10 min each) and incubated with the secondary antibodies (in PBS-1\% BSA for biotinylated antibodies, $2 \mathrm{~h}$ RT or in PBS- $0.2 \%$ fish gelatin for gold antibodies, overnight $4^{\circ} \mathrm{C}$ ). Biotinylated antibodies were revealed with the ABC Elite kit (in PBS, 1 h, RT; Vector Lab) and the peroxidase reaction was carried out in the presence of DAB and hydrogen peroxide (Sigma Fast, Sigma Aldrich). Nanogoldcoupled antibodies were amplified as described (Trembleau et al., 1994).

\section{ELECTRON MICROSCOPIC PRE-EMBEDDING NON-RADIOACTIVE IN SITUHYBRIDIZATION AND IMMUNOCYTOCHEMISTRY}

Fifty micrometer sections were cryoprotected and permeabilized as for EM immunocytochemistry. Prehybridization and hybridization were as described above for fluorescent ISH. After the stringency washes, sections were rinsed in PBS and incubated in the primary antibody in $1 \% \mathrm{BSA}$ in PBS, overnight, at $4^{\circ} \mathrm{C}$. After three PBS rinses (10 min each), DIG molecules and the primary antibody were detected by gold- and biotin-coupled antibodies, respectively in $0.8 \%$ BSA, $0.2 \%$ Fish Gelatin in PBS, overnight, $4^{\circ} \mathrm{C}$. After three PBS rinses (10 min each) sections were incubated in 4\% PFA in PBS (10 min), rinsed three times in PBS (10 min each) and several times in cold distillated water. Gold-coupled sheep anti-DIG secondary antibodies were detected by a silver enhancement-gold toning protocol as described (Trembleau et al., 1994). After three PBS rinses (10 min each), biotinylated antibodies were detected by peroxidase-DAB reaction as in classical immunocytochemical methods.

The sections processed for immunocytochemistry and ISH were dehydrated, osmicated and flat embedded in araldite (Fluka) resin. Ultrathin sections were prepared, mounted in copper grids and contrasted with uranyl acetate and lead citrate before examination under a Jeol CX II transmission electron microscope at $80 \mathrm{kV}$.

\section{ELECTRON MICROSCOPIC POST-EMBEDDING IMMUNOCYTOCHEMISTRY}

Vibratome $200 \mu \mathrm{m}$ thick sections were cryoprotected with $2 \mathrm{M}$ sucrose in PBS, rapidly frozen in liquid propane, cryosubstituted and infiltrated with HM20 resin (Polysciences, Germany) in a cryosubstitution unit (AFS; Reichert). Polymerization was induced by UV light for 3 days, at $-45^{\circ} \mathrm{C}$. Ultrathin sections were prepared and mounted on formvar-coated 400 mesh nickel grids and processed for immunocytochemistry as follows. Sections were etched in a saturated sodium ethanolate solution for $2 \mathrm{~s}$ and rinsed in distilled $\mathrm{H}_{2} \mathrm{O}$. After $10 \mathrm{~min}$ in $0.1 \% \mathrm{NaBH}_{4}, 50 \mathrm{mM}$ Glycine in Tris Buffered Saline (TBS) (50 mM, pH 7.4, 50 mM TBS) the grids were rinsed by three washes of $50 \mathrm{mM}$ TBS (10 min each). Grids were incubated in drops containing the primary antibodies in $50 \mathrm{mM}$ TBS, overnight or $48 \mathrm{~h}$ at $4^{\circ} \mathrm{C}$. Unbound primary antibodies were removed by $50 \mathrm{mM}$ TBS washes and by incubating grids in drops of TBS (10 min) and $150 \mathrm{mM}$ TBS (10 min, three times each). Primary antibodies were revealed by immunoglobulins coupled to calibrated gold particles (10 and $15 \mathrm{~nm}$; British BioCell Int.) in Polyethylene Glycol 20000 ( $5 \mathrm{mg} / \mathrm{ml} \mathrm{PEG),2 \%} \mathrm{BSA} \mathrm{in} 150 \mathrm{mM} \mathrm{TBS}, 2 \mathrm{~h}$ at $37^{\circ} \mathrm{C}$. The sections were then rinsed several times in $50 \mathrm{mM}$ TBS, and stabilized in $2 \%$ glutaraldehyde in $50 \mathrm{mM}$ TBS. Finally, after several washes in $\mathrm{H}_{2} \mathrm{O}$, the grids were contrasted with uranyl acetate and lead citrate and examined under a Jeol CX transmission electron microscope at $80 \mathrm{kV}$.

\section{IMAGING CONTROLS}

Sense and random oligonucleotide probes and omission of any oligonucleotide or primary antibody or any single major step in the development of DAB reactions, fluorescent ISH and immunocytochemistry resulted in no labeling of any cells. All the oligonucleotide probes and antibodies used have been described and fully characterized previously (Malosio et al., 1991; Sato et al., 1991; Buckanovich et al., 1993, 1996; Racca et al., 1997 1998). For doublefluorescence experiments, controls included either the independent omission of each single major step of the immunocytochemistry and/or ISH protocols, one at a time, or the replacement of the primary antibody by normal goat serum (Invitrogen; see Figure $\mathbf{S} 1$ in Supplementary Material).

\section{NOVA CLIP}

Nova cytoplasmic HITS-CLIP was performed as described previously (Licatalosi et al., 2008), with minor modification. After the brain was UV-irradiated to covalently crosslink RNA-protein complexes, nuclear/cytoplasmic fractionation was performed as described above. In brief, extracts were then partially RNased to reduce the modal size of cross-linked RNA bound to Nova to $\sim 50$ nt. Extracts were immunoprecipitated with a Nova1-specific antibody (Millipore), RNA linkers added with T4 RNA ligase, complexes purified by SDS-PAGE, protein removed with proteinase $\mathrm{K}$, and RNA sequenced by reverse transcription and sequencing with an Illumina Bioanalyzer. One brain was utilized for Nova1 cytoplasmic CLIP which yielded total 1,504,346 tags, 815,172 of which were able to be mapped to the mouse genome and 48,518 of which mapped to unique locations. These unique tags were used for analysis of cytoplasmic Nova binding sites in GlyR $\alpha 2$ and GIRK2 transcripts. Additional CLIP experiments used rabbit anti-Nova antibody to perform CLIP as described (Licatalosi et al., 2008), in biologic triplicate from mouse cortex (Figure 6A) and in biologic duplicate from mouse spinal cord (Figure 8B; Eom and Darnell, manuscript in preparation).

Nova HITS-CLIP binding sites were identified in the GIRK2 distal-most 3' UTR (GIRK2A or GIRK2-1 isoform; NM_001025584.2) using the UCSC genome browser. Similarly, the GIRK2 intron 2 binding site identified ( 187,000 nt upstream of the $3^{\prime}$ UTR) was: (>mm9, chr16:95160755-95160878: CCATTCCTTC ACTATCCACA GCCCAAAAGC TAAGTCCTAA TCTCTGCATC TTAAAGACCA ATGTAAATGA CCCATACATC ATCACCACCA TCATCTTCAT CTTTGTCATC ACTGTCCTCT TCAT).

\section{HETEROKARYON ASSAYS}

HEK293-T or COS7/NIH3T3 cells were plated on gelatin coated coverslips. For shuttling of overexpressed Nova, transfection was performed before plating IMR-32/SK-N-BE(2) cells. Fusion of 
two different cells was induced by using $50 \%$ polyethylene glycol (PEG 3350; Sigma Aldrich) in water for $2 \mathrm{~min}$. Cells were washed in PBS, and returned to medium containing $75 \mu \mathrm{g} / \mathrm{ml}$ cycloheximide for another $3 \mathrm{~h}$ incubation. Immunofluorescence was followed by fixation. HEK293-T, Neuro2a and COS7 cells were transfected with plasmid constructs by using Fugene6 (Roche) as described by manufacturer. After $24 \mathrm{~h}$, the cells were fixed in PFA (4\% in PBS) at RT for $15 \mathrm{~min}$.

\section{CONSTRUCTS}

T7-Noval have been described previously (Dredge and Darnell, 2003). Flag-tagged $\Delta$ NLS-Nova 1 and $\Delta$ NES-Nova 1 were generated by PCR mutagenesis, deleting amino acids 25-40 and amino acids 318-335, respectively. GIRK2 YCAY elements were amplified by PCR and added into the pd1EGFP-N1 vector (Clontech). Mutations to YCAY elements were made by using QuickChange site-directed mutagenesis kit (Stratagene). In order to avoid effects from diffusion, the M9-NLS was added into vector.

GIRK2 YCAY primers are listed in Supplementary Material.

\section{IMMUNOFLUORESCENCE IN CULTURED CELLS}

For detection of proteins, we used monoclonal antibodies to T7 (Novagen), Flag (Sigma Aldrich) and hnRNP-C1 (generous gift from Dr. Piñol-Roma), and POMA serum for Nova proteins. All secondary antibodies were affinity-purified donkey antibodies to mouse or human IgG conjugated to a fluorochrome (Jackson Immunoresearch). Antibody incubations were for $1 \mathrm{~h}$ at RT in TBS with BSA (1\%) and Triton X-100 (0.1\%). Coverslips were mounted with Prolong gold antifade reagent (Invitrogen). Primary neuronal cultures were generated from E18.5 cortical neurons prepared as described (Eom et al., 2003). Cells were fixed at 14 DIV for immunofluorescence staining with MAP2 monoclonal antibody (Sigma Aldrich) or FISH.

\section{FLUORESCENCE IN SITU HYBRIDIZATION (FISH) IN CULTURED CELLS}

Five amino-modified oligonucleotide probes (approximately 50 nts each; see Supplementary Material) were designed to mouse GIRK2 mRNA and synthesized on a DNA synthesizer incorporating five amino-modified thymidines (C6dT), purified and chemically labeled using fluorophores (Cy3; Amersham) as described (http://www.singerlab.org/protocols). In situ

\section{REFERENCES}

Altschuler, R. A., Betz, H., Parakkal, M. H., Reeks, K. A., and Wenthold, R. J. (1986). Identification of glycinergic synapses in the cochlear nucleus through immunocytochemical localization of the postsynaptic receptor. Brain Res. 369, 316-320.

Arn, E.A., Cha, B. J., Theurkauf, W.E., and Macdonald, P.M. (2003). Recognition of a bicoid mRNA localization signal by a protein complex containing Swallow, Nod, and RNA binding proteins. Dev. Cell 4, 41-51.

Ashraf, S. I., McLoon, A. L., Sclarsic, S. M., and Kunes, S. (2006). Synaptic protein

hybridization was completed as previously described (Eom et al., 2003). Coverslips were mounted with Prolong gold antifade reagent (Invitrogen).

\section{QUANTITATIVE ANALYSIS}

For image acquisition, exposure times and other settings were kept constant within the same experiment. In order to avoid bias in quantitation, regions of interest (ROI) were first chosen from fluorescence images of MAP2 (a dendritic marker) and were then transferred onto the fluorescent image of the same cell. The ROI was chosen 5-10 $\mu \mathrm{m}$ from the cell soma to specifically capture dendritic images. Total fluorescent intensities were collected from the same ROI for FISH, GFP or MAP2. A mask covering the dendrite was created based on MAP2 signals, and the fluorescent intensity signals of FISH or GFP was normalized to that of MAP2. In FISH analysis, the Cy5 channel was used for MAP2 analysis, Cy3 for FISH analysis. In GFP analysis, the Cy3 channel was used for MAP2 and Cy2 for GFP analysis. Quantitative analysis was performed by determining normalized fluorescence (pixel) intensities in neurites. Student's $t$-test was applied to measure statistical significance. More than 10 cells were counted.

\section{ACKNOWLEDGMENTS}

The authors thank members of our laboratories for discussion, and Yoshika Hayakawa-Yano for critical review of the manuscript. Help with post-embedding electron microscopy from P. Rostaing was greatly appreciated. We thank Dr. DeCamilli (Yale University Medical School) for the anti-synapsin antibody, and Dr. PiñolRoma for the anti-hnRNP-C1 antibody. Claudia Racca and this work were initially supported by: an EC TMR Marie Curie Research Training Grant. This work was supported by grants from Association France Myopathies, Fondation pour la Recherche Médicale, Société de Secours des Amis des Sciences and Human Frontiers Science Programme (Alejandra Gardiol, Antoine Triller), and from the National Institutes of Health (R01 NS34389 and NS40955; Robert B. Darnell). Robert B. Darnell is an Investigator of the Howard Hughes Medical Institute.

\section{SUPPLEMENTARY MATERIAL}

The Supplementary Material for this article can be found online at http://www.frontiersin.org/neuralcircuits/paper/10.3389/ neuro.04/005.2010/

mammalian brain. Proc. Natl. Acad. Sci. U.S.A. 76, 5982-5986.

Bramham, C. R., Worley, P. F., Moore, M. J., and Guzowski, J. F. (2008). The immediate early gene arc/arg3.1: regulation, mechanisms, and function. $J$. Neurosci. 28, 11760-11767.

Buckanovich, R. J., and Darnell, R. B. (1997). The neuronal RNA binding protein Nova-1 recognizes specific RNA targets in vitro and in vivo. $\mathrm{Mol}$. Cell. Biol. 17, 3194-3201.

Buckanovich, R. J., Posner, J. B., and Darnell, R. B. (1993). Nova, the paraneoplastic $\mathrm{Ri}$ antigen, is homologous to an RNA-binding protein and is specifically expressed in the developing motor system. Neuron 11, 657-672.

Buckanovich, R. J., Yang, Y.Y., and Darnell, R. B. (1996). The onconeural antigen Nova-1 is a neuron-specific RNAbinding protein, the activity of which is inhibited by paraneoplastic antibodies. J. Neurosci. 16, 1114-1122.

Darnell, R. B. (2006). Developing global insight into RNA regulation. Cold Spring Harb. Symp. Quant. Biol. 71, 321-327.

Darnell, R. B., and Posner, J. B. (2003). Paraneoplastic syndromes involving the nervous system. N. Engl. J. Med. 349, 1543-1554. 
Darnell, R. B., and Posner, J. B. (2006). Paraneoplastic syndromes affecting the nervous system. Semin. Oncol.33, 270-298.

De Camilli, P., Cameron, R., and Greengard, P. (1983). Synapsin I (protein I), a nerve terminal-specific phosphoprotein. I. Its general distribution in synapses of the central and peripheral nervous system demonstrated by immunofluorescence in frozen and plastic sections. J. Cell Biol. 96, 1337-1354.

De Camilli, P., Ueda, T., Bloom, F. E., Battenberg, E., and Greengard, P. (1979). Widespread distribution of protein I in the central and peripheral nervous systems. Proc. Natl. Acad. Sci. U.S.A. 76, 5977-5981.

Dredge, B. K., and Darnell, R. B. (2003). Nova regulates GABA(A) receptor gamma2 alternative splicing via a distal downstream UCAU-rich intronic splicing enhancer. Mol. Cell. Biol. 23, 4687-4700.

Dredge, B. K., Stefani, G., Engelhard, C. C., and Darnell, R. B. (2005). Nova autoregulation reveals dual functions in neuronal splicing. EMBO J. 24, 1608-1620.

Ehlers, M.D., Tingley, W. G., and Huganir, R. L. (1995). Regulated subcellular distribution of the NR1 subunit of the NMDA receptor. Science 269, 1734-1737.

Elf, J., Li, G. W., and Xie, X. S. (2007). Probing transcription factor dynamics at the single-molecule level in a living cell. Science 316, 1191-1194.

Eom, T., Antar, L. N., Singer, R. H., and Bassell, G. J. (2003). Localization of a beta-actin messenger ribonucleoprotein complex with zipcode-binding protein modulates the density of dendritic filopodia and filopodial synapses. J. Neurosci. 23, 10433-10444.

Gardiol, A., Racca, C., and Triller, A. (1999). Dendritic and postsynaptic protein synthetic machinery. $J$. Neurosci. 19, 168-179.

Giorgi, C., and Moore, M. J. (2007). The nuclear nurture and cytoplasmic nature of localized mRNPs. Semin. Cell Dev. Biol. 18, 186-193.

Gorman, J., Chowdhury, A., Surtees, J. A., Shimada, J., Reichman, D. R., Alani, E., and Greene, E. C. (2007). Dynamic basis for one-dimensional DNA scanning by the mismatch repair complex Msh2-Msh6. Mol. Cell 28, 359-370.

Gorman, J., and Greene, E. C. (2008). Visualizing one-dimensional diffusion of proteins along DNA. Nat. Struct. Mol. Biol. 15, 768-774.

Grenningloh, G., Gundelfinger, E., Schmitt, B., Betz, H., Darlison, M. G., Barnard, E. A., Schofield, P. R., and Seeburg, P. H. (1987). Glycine vs GABA receptors. Nature 330 , 25-26.

Gu, W., Pan, F., Zhang, H., Bassell, G. J., and Singer, R. H. (2002). A predominantly nuclear protein affecting cytoplasmic localization of beta-actin mRNA in fibroblasts and neurons. $J$. Cell Biol. 156, 41-51.

Hachet, O., and Ephrussi, A. (2001). Drosophila Y14 shuttles to the posterior of the oocyte and is required for oskar mRNA transport. Curr. Biol. 11, 1666-1674.

Hachet, O., and Ephrussi, A. (2004). Splicing of oskar RNA in the nucleus is coupled to its cytoplasmic localization. Nature 428, 959-963.

Holt, C. E., and Bullock, S. L. (2009). Subcellular mRNA localization in animal cells and why it matters. Science 326, 1212-1216.

Huang, C. S., Shi, S. H., Ule, J., Ruggiu, M., Barker, L. A., Darnell, R. B., Jan, Y. N., and Jan, L. Y. (2005). Common molecular pathways mediate longterm potentiation of synaptic excitation and slow synaptic inhibition. Cell 123, 105-118.

Jensen, K. B., and Darnell, R. B. (2008). CLIP: crosslinking and immunoprecipitation of in vivo RNA targets of RNA-binding proteins. Methods Mol. Biol. 488, 85-98.

Jensen, K. B., Dredge, B. K., Stefani, G., Zhong, R., Buckanovich, R. J., Okano, H. J., Yang, Y. Y., and Darnell, R. B. (2000). Nova-1 regulates neuron-specific alternative splicing and is essential for neuronal viability. Neuron 25, 359-371.

Kataoka, N., Yong, J., Kim, V.N., Velazquez, F., Perkinson, R. A., Wang, F., and Dreyfuss, G. (2000). Pre-mRNA splicing imprints mRNA in the nucleus with a novel RNA-binding protein that persists in the cytoplasm. Mol. Cell 6, 673-682.

Kislauskis, E. H., and Singer, R. H. (1992). Determinants of mRNA localization. Curr. Opin. Cell Biol. 4, 975-978.

Kislauskis, E. H., Zhu, X., and Singer, R. H. (1997). beta-Actin messenger RNA localization and protein synthesis augment cell motility. J. Cell Biol. 136, 1263-1270.

Kress, T. L., Yoon, Y. J., and Mowry, K. L. (2004). Nuclear RNP complex assembly initiates cytoplasmic RNA localization. J. Cell Biol. 165, 203-211.

Kuhse, J., Kuryatov, A., Maulet, Y., Malosio, M. L., Schmieden, V., and Betz, H. (1991). Alternative splicing generates two isoforms of the a2 subunit of the inhibitory glycine receptor. FEBS Lett. 283, 73-77.

Kuhse, J., Schmieden, V., and Betz, H. (1990). A single amino acid exchange alters the pharmacology of neonatal rat glycine receptor subunit. Neuron 5, 867-873.

Lawrence, J. B., and Singer, R. H. (1986). Intracellular localization of messenger RNAs for cytoskeletal proteins. Cell 45 , 407-415.

Le Hir, H., Moore, M. J., and Maquat, L. E. (2000). Pre-mRNA splicing alters mRNP composition: evidence for stable association of proteins at exon-exon junctions. Genes Dev. 14, 1098-1108.

Lewis, H. A., Musunuru, K., Jensen, K. B. Edo, C., Chen, H., Darnell, R. B., and Burley, S. K. (2000). Sequence-specific RNA binding by a Nova KH domain implications for paraneoplastic disease and the fragile $\mathrm{X}$ syndrome. Cell 100, 323-332.

Licatalosi, D. D., and Darnell, R. B. (2010) RNA processing and its regulation: global insights into biological networks. Nat. Rev. Genet. 11, 75-87.

Licatalosi, D. D., Mele, A., Fak, J. J., Ule, J., Kayikci, M., Chi, S. W., Clark, T. A., Schweitzer,A.C., Blume, J.E., Wang, X. Darnell, J.C., and Darnell, R. B. (2008). HITS-CLIP yields genome-wide insights into brain alternative RNA processing. Nature 456, 464-469.

Lin, A. C., and Holt, C. E. (2007). Local translation and directional steering in axons. EMBO J. 26, 3729-3736.

Luo, M. J., and Reed, R. (1999). Splicing is required for rapid and efficient mRNA export in metazoans. Proc. Natl. Acad. Sci. U.S.A. 96, 14937-14942.

Malim, M. H., and Cullen, B. R. (1991) HIV-1 structural gene expression requires the binding of multiple Rev monomers to the viral RRE: implications for HIV-1 latency. Cell 65 241-248.

Malosio, M. L., Marqueze-Pouey, B., Kuhse, J., and Betz, H. (1991). Widespread expression of glycine receptor subunit mRNAs in the adult and developing rat brain. EMBO J. 10 2401-2409.

Martin, K. C., and Ephrussi, A. (2009) mRNA localization: gene expression in the spatial dimension. Cell 136, 719-730.

Miller, P. S., Harvey, R. J., and Smart, T. G. (2004). Differential agonist sensitivity of glycine receptor alpha2 subunit splice variants. Br. J. Pharmacol. 143 19-26.

Moss, S. J., and Smart, T. G. (2001). Constructing inhibitory synapses. Nat. Rev. Neurosci. 2, 240-250.

Mu, Y., Otsuka, T., Horton, A. C., Scott, D. B., and Ehlers, M. D. (2003). Activitydependent mRNA splicing controls ER export and synaptic delivery of NMDA receptors. Neuron 40, 581-594.

Musunuru, K., and Darnell, R. B. (2001). Paraneoplastic neurologic disease
antigens-RNA-binding proteins and signaling proteins in neuronal degeneration. Annu. Rev. Neurosci. 24, 239-262.

Palacios, I. M. (2002). RNA processing: splicing and the cytoplasmic localisation of mRNA. Curr. Biol. 12, R50-R52.

Palacios, I. M., Gatfield, D., St Johnston, D., and Izaurralde, E. (2004). An eIF4AIIIcontaining complex required for $\mathrm{mRNA}$ localization and nonsense-mediated mRNA decay. Nature 427, 753-757.

Palacios, I. M., and St Johnston, D. (2001). Getting the message across: the intracellular localization of mRNAs in higher eukaryotes. Annu. Rev. Cell Dev. Biol. 17, 569-614.

Peters, A., Palay, S. L., and Webster, H. d. (1991). The Fine Structure of the Nervous System: Neurons and Their Supporting Cells. New York, Oxford, Oxford University Press.

Pfeiffer, F., Simler, R., Grenningloh, G., and Betz, H. (1984). Monoclonal antibodies and peptide mapping reveal structural similarities between the subunits of the glycine receptor of rat spinal cord. Proc. Natl. Acad. Sci. U.S.A. 81, 7224-7227.

Pinol-Roma, S., and Dreyfuss, G. (1992) Shuttling of pre-mRNA binding proteins between nucleus and cytoplasm. Nature 355, 730-732.

Polydorides, A. D., Okano, H. J., Yang, Y.Y., Stefani, G., and Darnell, R. B. (2000).A brain-enriched polypyrimidine tractbinding protein antagonizes the ability of Nova to regulate neuron-specific alternative splicing. Proc. Natl. Acad. Sci. U.S.A. 97, 6350-6355.

Racca, C., Gardiol, A., and Triller, A. (1997). Dendritic and postsynaptic localizations of glycine receptor alpha subunit mRNAs. J. Neurosci. 17, 1691-1700.

Racca, C., Gardiol, A., and Triller, A. (1998). Cell-specific dendritic localization of glycine receptor alpha subunit messenger RNAs. Neuroscience 84, 997-1012.

Richter, J. D. (2007). CPEB: a life in translation. Trends Biochem. Sci. 32, 279-285.

Richter, J.D., and Klann,E. (2009). Making synaptic plasticity and memory last: mechanisms of translational regulation. Genes Dev. 23, 1-11.

Rodriguez, A. J., Czaplinski, K., Condeelis, J. S., and Singer, R. H. (2008). Mechanisms and cellular roles of local protein synthesis in mammalian cells. Curr. Opin. Cell Biol. 20, 144-149.

Ruggiu, M., Herbst, R., Kim, N., Jevsek, M., Fak, J. J., Mann, M. A., Fischbach, G., Burden, S. J., and Darnell, R. B. (2009). Rescuing Z+ agrin splicing in Nova 
null mice restores synapse formation and unmasks a physiologic defect in motor neuron firing. Proc. Natl. Acad. Sci. U.S.A. 106, 3513-3518.

Sato, K., Zhang, J. H., Saika, T., Sato, M., Tada, K., and Tohyama, M. (1991). Localization of glycine receptor alpha 1 subunit mRNA-containing neurons in the rat brain: an analysis using in situ hybridization histochemistry. Neuroscience 43, 381-395.

Schuman, E. M., Dynes, J. L., and Steward, O. (2006). Synaptic regulation of translation of dendritic mRNAs. J. Neurosci. 26, 7143-7146.

St Johnston, D. (2005). Moving messages: the intracellular localization of mRNAs. Nat. Rev. Mol. Cell Biol. 6, 363-375.

Steward, O., and Schuman, E. M. (2001). Protein synthesis at synaptic sites on dendrites. Annu. Rev. Neurosci. 24, 299-325.

Sutton, M.A., and Schuman, E. M. (2006). Dendritic protein synthesis, synaptic plasticity, and memory. Cell 127, 49-58.

Trembleau, A., Morales, M., and Bloom, F. E. (1994). Aggregation of vasopressin mRNA in a subset of axonal swellings of the median eminence and posterior pituitary:light and electron microscopic evidence. J. Neurosci. 14, 39-53.

Triller,A., Cluzeaud, F., and Korn, H. (1987). gamma-Aminobutyric acid-containing terminals can be apposed to glycine receptors at central synapses. J. Cell Biol. 104, 947-956.

Triller, A., Cluzeaud, F., Pfeiffer, F., Betz, H., and Korn, H. (1985). Distribution of glycine receptors at central synapses: an immunoelectron microscopy study. J. Cell Biol. 101, 683-688.

Ule, J., and Darnell, R. B. (2006). RNA binding proteins and the regulation of neuronal synaptic plasticity. Curr. Opin. Neurobiol. 16, 102-110.

Ule, J., Jensen, K., Mele, A., and Darnell, R. B. (2005). CLIP: a method for identifying protein-RNA interaction sites in living cells. Methods 37, 376-386.

Ule, J., Jensen, K. B., Ruggiu, M., Mele, A., Ule, A., and Darnell, R. B. (2003). CLIP identifies Nova-regulated RNA networks in the brain. Science 302, 1212-1215.

Ule, J., Stefani, G., Mele, A., Ruggiu, M., Wang, X., Taneri, B., Gaasterland, T., Blencowe, B. J., and Darnell, R. B. (2006). An RNA map predicting
Nova-dependent splicing regulation. Nature 444, 580-586.

Ule, J., Ule, A., Spencer, J., Williams, A., Hu, J. S., Cline, M., Wang, H., Clark, T., Fraser, C., Ruggiu, M., Zeeberg, B. R., Kane, D., Weinstein, J. N., Blume, J., and Darnell, R. B. (2005). Nova regulates brain-specific splicing to shape the synapse. Nat. Genet. 37, 844-852.

Visnapuu, M. L., and Greene, E. C. (2009). Single-molecule imaging of DNA curtains reveals intrinsic energy landscapes for nucleosome deposition. Nat. Struct. Mol. Biol. 16, 1056-1062.

Wang, E. T., Sandberg, R., Luo, S., Khrebtukova, I., Zhang, L., Mayr, C., Kingsmore, S. F., Schroth, G. P., and Burge, C. B. (2008). Alternative isoform regulation in human tissue transcriptomes. Nature 456, 470-476.

Yang, Y. Y., Yin, G. L., and Darnell, R. B. (1998). The neuronal RNA-binding protein Nova-2 is implicated as the autoantigen targeted in POMA patients with dementia. Proc. Natl. Acad. Sci. U.S.A. 95, 13254-13259.

Zhu, J., Mayeda, A., and Krainer, A. R. (2001). Exon identity established through differential antagonism between exonic splicing silencerbound hnRNP A1 and enhancerbound SR proteins. Mol. Cell 8, 1351-1361.

Conflict of Interest Statement: The authors declare that the research was conducted in the absence of any commercial or financial relationships that could be construed as a potential conflict of interest.

Received: 31 July 2009; paper pending published: 03 December 2009; accepted: 01 February 2010; published online: 03 March 2010.

Citation: Racca C, Gardiol A, Eom T, Ule J, Triller A and Darnell RB (2010) The neuronal splicing factor Nova colocalizes with target RNAs in the dendrite. Front. Neural Circuits 4:5. doi: 10.3389/neuro.04.005.2010

Copyright (C) 2010 Racca, Gardiol, Eom, Ule, Triller and Darnell. This is an openaccess article subject to an exclusive license agreement between the authors and the Frontiers Research Foundation, which permits unrestricted use, distribution, and reproduction in any medium, provided the original authors and source are credited. 